\title{
Myc-mediated apoptosis requires wild-type p53 in a manner independent of cell cycle arrest and the ability of p53 to induce p21 waf1/cip1
}

\author{
Andrew J. Wagner, ${ }^{1}$ John M. Kokontis, and Nissim Hay ${ }^{2,3}$ \\ The Ben May Institute and the Departments of ${ }^{1}$ Biochemistry and Molecular Biology and ${ }^{2}$ Pharmacological \\ and Physiological Sciences, The University of Chicago, Chicago, Illinois 60637 USA
}

Deregulated expression of the c-myc proto-oncogene can lead to apoptosis under certain physiological conditions. By introducing a conditionally active Myc allele into primary embryo fibroblasts null for p53, and into fibroblasts without endogenous p53 expression but ectopically expressing a temperature-sensitive p53 allele, we show that expression of wild-type p53 is required for susceptibility to Myc-mediated apoptosis. Although ectopic expression of wild-type $p 53$ blocked cells in the $G_{1}$ phase of the cell cycle, $G_{1}$ arrest by isoleucine starvation, in a manner independent of p53, did not confer susceptibility to apoptosis. Thus, growth arrest per se is not sufficient to induce Myc-mediated apoptosis; instead, a property intrinsic to p53 is specifically required. Moreover, apoptosis did not require induction of p53 target proteins, including the cyclin-dependent kinase inhibitor $\mathrm{p} 21^{\text {waf1/cip } 1}$. Therefore, the role of $\mathrm{p} 53$ in apoptosis may be distinct from its role in cell cycle arrest.

[Key Words: Oncogene; tumor suppressor; programmed cell death]

Received August 12, 1994; revised version accepted October 13, 1994.

The regulation of cell proliferation involves a delicate balance between the actions of proto-oncogenes and tumor supressor genes. Deregulation or inactivation of either set of genes can lead to uncontrolled cell proliferation, terminal cell cycle arrest, or enhanced activation of programmed cell death (apoptosis), all of which have potentially devastating consequences to an organism. Thus, tremendous selective pressure must exist for the evolution of mechanisms to regulate these genes, at the levels of both the synthesis and activities of their gene products.

The c-myc proto-oncogene plays an important role in the control of proliferation and differentiation (for review, see Cole 1986; Lüscher and Eisenman 1990; Kato and Dang 1992; Marcu et al. 1992; Evan and Littlewood 1993|. Expression of Myc is required and in some cases sufficient for the $G_{1} / S$ phase transition (Eilers et al. 1991; Evan et al. 1992; Wagner et al. 1993b), and enforced expression of Myc can prevent cellular differentiation (Marcu et al. 1992). In addition, Myc may also play a role in the $G_{2} / M$ transition (Shibuya et al. 1992; Wagner et al. 1993b). Furthermore, deregulated Myc expression has been observed in a variety of neoplasias, and experimental overexpression of Myc in cells and animals

\footnotetext{
${ }^{3}$ Corresponding author.
}

has led to cellular transformation and oncogenesis (for review, see Cole 1986; Cory 1986; Bishop 1991; Spencer and Groudine 1991; Marcu et al. 1992).

The mechanisms by which Myc exerts such profound effects on the regulation of cell cycle progression have until recently remained obscure. Descriptions of Myc as a sequence-specific transcriptional activator (Benvenisty et al. 1992; Kretzner et al. 1992; Reddy et al. 1992; Amin et al. 1993; Reisman et al. 1993) suggest that Myc may act by directly regulating expression of proteins required for cell cycle progression, such as ornithine decarboxylase (Bello-Fernandez et al. 1993; Wagner et al. 1993a) and the $\mathrm{G}_{1}$ cyclins (Jansen-Dürr et al. 1993 and A.J. Wagner and N. Hay, unpubl.). This possibility is strengthened by the observation that regions of the Myc protein that are required for transcriptional activation colocalize to those required for transformation (Stone et al. 1987; Kato et al. 1990; Amin et al. 1993). Myc may also suppress the expression of genes associated with growth arrest and differentiation (Freytag and Geddes 1992). In addition, Myc has been reported to interact with the tumor suppressor p107 (Gu et al. 1994), and this association may also play a role in cell cycle control.

Myc has also been paradoxically demonstrated to induce programmed cell death when expressed without appropriate growth factor stimulation or in cells arrested by other means (Askew et al. 1991; Evan et al. 1992; Shi 
et al. 1992). These opposing Myc-inducible pathways of cell cycle progression and cell death lend an extra level of complexity to tumorigenesis induced by Myc deregulation. That is, what determines to which route Myc deregulation will lead? And how do tumors arise from cells in which Myc is deregulated?

One possible mechanism is that in the context of an inhibited or blocked cell death pathway, Myc overexpression will favor proliferation and tumor formation. If this is the case, tumors with deregulated Myc expression should contain a second genetic lesion that inactivates the cell death pathway. Several models of Myc-induced tumorigenesis support this concept, because coexpression of a second oncogene or activation of a collaborator accelerates the rate of tumor formation (Haupt et al. 1991; Möröy et al. 1991; van Lohuizen et al. 1991). This mechanism can be tested experimentally by interference with the cell death pathway, either by overexpression of genes that block cell death or by disruption of genes required for cell death.

Previous work by our laboratory and others has demonstrated that overexpression of the bcl-2 proto-oncogene can inhibit Myc-mediated apoptosis in Rat la fibroblasts (Fanidi et al. 1992; Wagner et al. 1993b) and in Chinese hamster ovary cells (Bissonnette et al. 1992). This observation may account for the natural history of the most common form of human follicular lymphomas, which arise as indolent tumors blocked in cell death due to overexpression of $\mathrm{Bcl}-2$ but frequently progress into aggressive malignancies following Myc deregulation (McDonnell and Korsmeyer 1991; Reed 1994). That is, disruption of the cell death pathway allows cells to tolerate Myc deregulation and leads to a more rampant malignancy. This situation is likewise observed in transgenic animals harboring Bcl-2 transgenes, which also develop lymphomas with Myc deregulation (McDonnell and Korsmeyer 1991).

We have speculated previously that the p 53 tumor supressor may play a role in regulating Myc-mediated apoptosis as well (Wagner et al. 1993b). This speculation is based on the following suggestive observations: (1) p53 is frequently mutated, deleted, or inactivated in a variety of tumors and tumor cell lines that exhibit myc deregulation or amplification. These include the myeloid leukemia cell line HL60, which has amplification of the c-myc gene and deletion of $p 53$ (Dalla-Favera et al. 1982; Wolf and Rotter 1985); small cell lung carcinomas, which have amplification of $\mathrm{L}$ - or c-myc and p53 mutations (Nau et al. 1985; Takahashi et al. 1990); and Burkitt lymphomas and pre- $B$ and $T$ cell acute lymphoblastic leukemias, which have deregulation of $c-m y c$ and $p 53$ mutations (Farrell et al. 1991; Wiman et al. 1991). (2) p53 is required for apoptosis induced by $\gamma$-irradiation and by chemotherapeutic drugs in cells sensitized by overexpression of the adenovirus E1A oncogene (Lowe et al. 1993a,b), which is similar to Myc in its ability to transform cells. (3) Exogenous expression of p53 in tumor cell lines with mutant or deleted $p 53$ genes can induce apoptosis (Yonisch-Rouach et al. 1991; Shaw et al. 1992; Ramqvist et al. 1993; Wang et al. 1993a). (4) Myc has been demonstrated to trans-activate the $\mathrm{p} 53$ promoter and thus may induce expression of p53 (Reisman et al. 1993).

To evaluate the requirement of p53 in Myc-mediated apoptosis, we examined the effect of Myc overexpression in primary cells and cell lines that do not express p53. We found that ectopic Myc expression does not induce apoptosis in primary cells or cell lines not expressing p53. Furthermore, introduction of a temperature-sensitive p53 allele resulted in susceptibility to Myc-induced apoptosis only when p53 was expressed in its wild-type conformation. Although expression of wild-type p53 led to growth arrest in the absence of active Myc, induction of Myc activity overcame this effect, driving cells into the cell cycle but leading to apoptosis. However, growth arrest by other means in the absence of wild-type p53 expression did not confer susceptibility to Myc-mediated apoptosis, suggesting that an activity intrinsic to p53 is necessary. Additionally, the p53-dependent apoptosis did not require de novo protein synthesis, including induction of the cyclin-dependent kinase (cdk) inhibitor $\mathrm{p} 21^{\text {waf1/cip } 1}$, which is thought to mediate p53-induced cell cycle arrest (El-Deiry et al. 1993; Harper et al. 1993; Xiong et al. 1993; Dulic et al. 1994). Thus, the requirement of p53 in conferring susceptibility to Myc-mediated apoptosis may be a function distinct from its ability to induce cell cycle arrest. These data demonstrate that wild-type p53 is specifically required for cell death induced by inappropriate expression of c-Myc and suggest that inactivation of p53 in tumors with deregulated Myc expression may be one mechanism by which cells have evaded control of tumorigenesis by cell death.

\section{Results}

Myc overexpression does not induce apoptosis

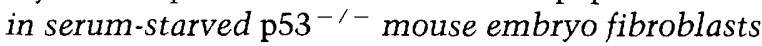

Deregulated Myc expression in cells without adequate growth factor stimulation has been demonstrated to lead to apoptosis in several cell lines (Askew et al. 1991; Evan et al. 1992). However, tumors in which Myc expression is deregulated are often able to escape cell death. One mechanism by which these tumors arise appears to be through the deregulation of $\mathrm{Bcl}-2$ expression, which in turn confers resistance to Myc-mediated apoptosis (Bissonnette et al. 1992; Fanidi et al. 1992; Wagner et al. 1993b). An alternative mechanism for escape from apoptosis may be through $p 53$ mutation, inactivation, or deletion, all of which are common events in tumorigenesis (for review, see Hollstein et al. 1991; Levine et al. 1991). Thus, we sought to examine the functional requirement of p53 expression in Myc-mediated apoptosis. To this end, we used retroviruses to constitutively express high levels of c-Myc in fibroblasts from 14.5-day mouse embryos with homozygous inactivation of both p53 alleles (Donehower et al. 1992; Harvey et al. 1993). Early-passage $p 53^{-1-}$ mouse embryo fibroblasts (MEFs) were infected with pMV12-Myc or pMV12 retroviruses (Wagner et al. 1993b) and cells with integrated retrovi- 
ruses were selected in hygromycin B. Ectopic Myc expression in $p 53^{-1-}$ MEFs was verified by Northern and Western blotting (data not shown). Following serum starvation, in conditions demonstrated previously to induce cell death in Rat 1a pMV12-Myc cells (Wagner et al. 1993b|, no significant cell death compared to wild-type $\left(p 53^{+1+}\right)$ MEFs or $p 53^{-1-}$ MEFs infected with the control virus (pMV12) was observed in any of the derived cell lines tested, including a pool and three independent clones of $p 53^{-/-}$MEFs overexpressing c-Myc (Fig. 1A,C).

We also infected wild-type and $p 53^{-1-}$ MEFs with retroviruses encoding a Myc-estrogen receptor fusion (MycER) protein. The MycER gene encodes a chimera of full length c-Myc and the ligand binding domain of the estrogen receptor (ER) (Eilers et al. 1989). Although it is constitutively expressed from the retroviral long terminal repeat promoter, it is a conditional Myc allele in that it requires $17 \beta$-estradiol (E2) or other ER agonists for activity. This protein has been demonstrated previously to be active in inducing transformation, cell cycle progression, transcription, and apoptosis (Eilers et al. 1989, 1991; Evan et al. 1992; Jansen-Dürr et al. 1993; Wagner et al. 1993a). Early-passage wild-type and $p 53^{-1-}$ MEFs were infected with pMV12-MycER retrovirus and were selected for hygromycin resistance in the absence of estradiol and phenol red (which has slight estrogenic activities) to prevent activation of the MycER fusion protein. This precludes selection of cells specifically resis-

A

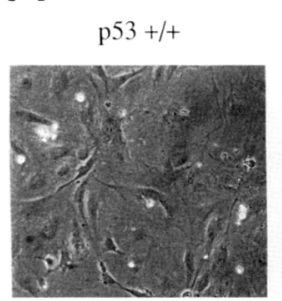

p53-1-

Myc. 1
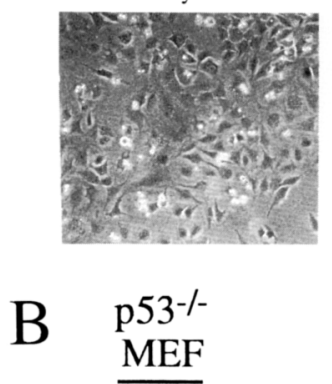

215

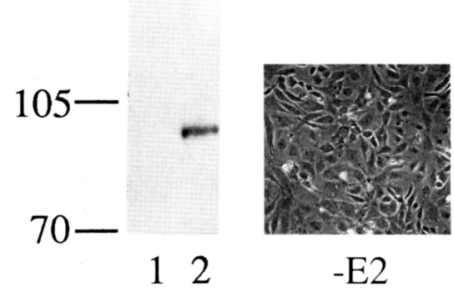

p53-1-

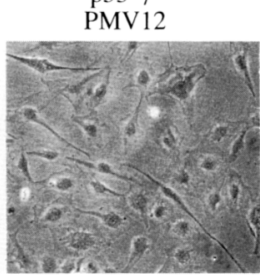

p53-/-

Myc.3
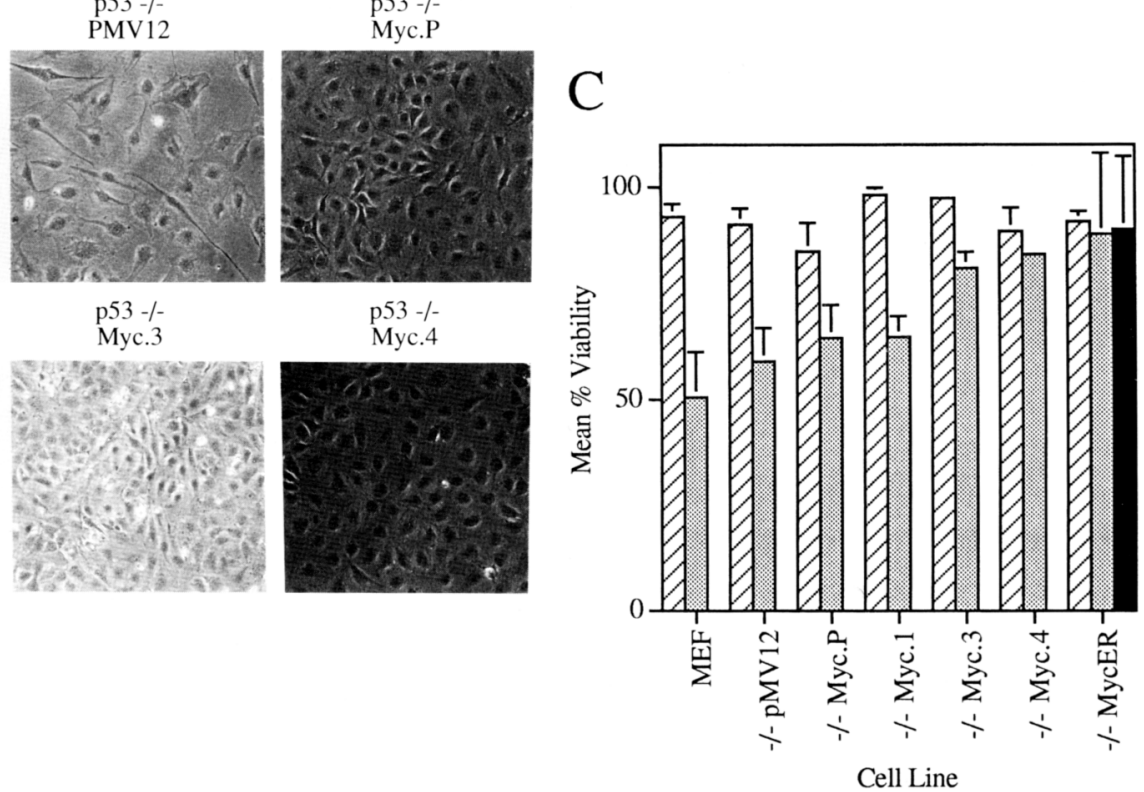

$\mathrm{D}$

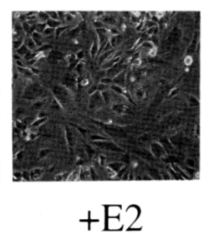

p53\%/- MEF

MycER

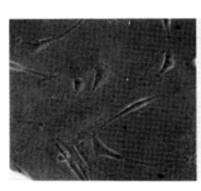

$-\mathrm{E} 2$

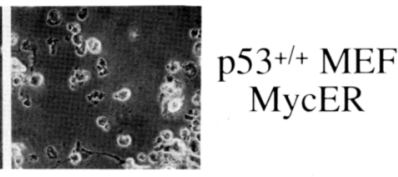

$+\mathrm{E} 2$

Figure 1. Overexpression of c-Myc does not induce cell death in serum-starved MEFs nullizygous for p53. $(A)$ Microscopic phenotypes of MEFs after $72 \mathrm{hr}$ incubation in DMEM with $0.1 \%$ FBS. Shown are wild-type (p53 + $/+\mid$ MEFs and fibroblasts from the p53 knockout mouse (p53 - / - ) infected with control (pMV12) or Myc-expressing retrovinuses. (Myc.P) Pool of Myc-expressing cells; (Myc.1, Myc.3, Myc.4) three independent clones of Myc-expressing cells. $(B)($ Left $)$ Western analysis of MycER expression in MEFs from the p53 knockout mouse. Total cellular proteins from $2 \times 10^{5}$ cells were analyzed by SDS-PAGE, transferred to nitrocellulose, and probed with a rat anti-human estrogen receptor monoclonal antibody $(\mathrm{H} 222)$. Antibody-antigen interactions were detected by enhanced chemiluminescence (ECL). (Lane 1) Lysate from cells infected with the control virus; (lane 2) lysate from cells infected with the MycER virus, displaying the $90-\mathrm{kD}$ MycER fusion protein. Migrations of molecular mass standards (in kilodaltons) are shown at left. (Right) Phenotype of serum-starved $p 53^{-1-}$ MEFs expressing MycER fusion protein in the absence (-E2) or presence (+E2) of $1 \mu \mathrm{M} 17 \beta-$ estradiol, $72 \mathrm{hr}$ after treatment. $(C)$ Viability of cells following serum starvation. Bars represent mean viability \pm S.E. of triplicate determinations. (Hatched bars) $0 \mathrm{hr}$ in $0.1 \% \mathrm{FBS}$; (stippled bars) $72 \mathrm{hr}$ in $0.1 \% \mathrm{FBS}$; (solid bar) $72 \mathrm{hr}$ in $0.1 \%$ FBS with $1 \mu \mathrm{M} 17 \beta$-estradiol $(E 2)$. (D) Phenotype of serum-starved $p 53^{+1+}$ MEFs expressing MycER fusion protein in the absence $(-\mathrm{E} 2)$ or presence $(+\mathrm{E} 2)$ of $1 \mu \mathrm{M}$ $17 \beta$-estradiol, $20 \mathrm{hr}$ after treatment. 
tant to Myc overexpression because the MycER in these cells was maintained in its inactive state. MycER expression in these cells was verified by Western analysis by use of a monoclonal antibody directed against ER (Fig. 1B). As observed with p53 knockout cells expressing constitutively active Myc, no apoptosis was observed in serum-starved p53 knockout cells in the absence (inactive Myc) or presence (active Myc) of E2 (Figs. 1B,C). Although we were repeatedly unable to establish hygromycin-resistant wild-type MEFs ectopically expressing constitutively active $\mathrm{c}-\mathrm{Myc}$, we were able to express the MycER fusion in wild type MEFs in the absence of E2. In these cells, treatment with E2 after serum starvation led to apoptosis (Fig. 1D). Thus, Myc overexpression in serum-starved primary cells not expressing p53 does not induce apoptosis, contrasting with previous observations in cells with wild-type p53, including serum-starved Rat la fibroblasts, rat embryo fibroblasts and WI-38 cells (normal human diploid lung fibroblasts; Evan et al. 1992; Wagner et al. 1993b; data not shown!).

\section{Restoration of wild-type p53 activity in $\mathrm{p} 53^{-/-}$cells results in cell cycle arrest}

To further elucidate the role of wild-type p53 in Mycmediated apoptosis, we turned to a MEF cell line that deleted large portions of both p53 alleles during immortalization and as a result expresses no detectable p53 mRNA or protein. This clonal cell line [(10.1)] (Harvey and Levine 1991) and a derivative transfected with temperature-sensitive p53 [(10.1) Val5] (Wu et al. 1993) were infected with pMV12-MycER or pMV12 retroviruses and selected in hygromycin B. Expression of p53 and MycER was verified by immunoprecipitation (not shown) and Western analysis (Fig. 2A), respectively. These resulting cell lines allow modulation of p53 activity by temperature shift and rapid induction of $\mathrm{Myc}$ activity by addition of $\mathrm{E} 2$.
The temperature-sensitive p53 allele has been demonstrated previously to be able to induce cell cycle arrest, differentiation, or apoptosis when expressed in cells at the permissive temperature (Diller et al. 1990; Michalovitz et al. 1990; Martinez et al. 1991; Yonisch-Rouach et al. 1991; Johnson et al. 1993; Wang et al. 1993a; Woodworth et al. 1993). Accordingly, we first analyzed the effect of wild-type p53 activity in the absence of overexpression of active Myc. Cell death and cell proliferation were analyzed by microscopy (Figs. 2B,C), analysis of growth rates (Fig. 3), and by flow cytometry (Fig. 4). In the absence of E2, the growth rate of $\{10.1\}$ MycER cells was not significantly altered by shift to $33^{\circ} \mathrm{C}$ as compared to the rate at $39^{\circ} \mathrm{C}$ (Figs. $2 \mathrm{~B}$ and $3 \mathrm{~A}$ ). However, (10.1)Val5 MycER cells were noticeably growth arrested at $33^{\circ} \mathrm{C}$ (Figs. $2 \mathrm{C}$ and $3 \mathrm{~B}$ ). Flow cytometric cell cycle analysis confirmed that these cells arrested in the $G_{1}$ phase of the cell cycle (Fig. 4A; Table 1). This agrees with previous reports that $\mathrm{p} 53$, when expressed in its wildtype conformation, can induce cell cycle arrest in these cells and others (Diller et al. 1990; Mercer et al. 1990; Michalovitz et al. 1990; Martinez et al. 1991; Wu and Levine 1994). Control cells infected with pMV12 retroviruses behaved exactly as their non-E2-treated MycERexpressing counterparts (data not shown).

\section{Myc overexpression overcomes p53-mediated growth arrest and induces apoptosis}

To evaluate the effect of Myc overexpression in cells with and without wild-type or mutant p53, (10.1) MycER and (10.1)Val5 MycER cells were incubated in medium containing $10 \%$ fetal bovine serum at $33^{\circ} \mathrm{C}$ or $39^{\circ} \mathrm{C}$ for 24 $\mathrm{hr}$ and were then treated with $1 \mu \mathrm{M}$ E2 or left untreated (Fig. 2B,C). Flow cytometric analysis indicated that activation of the MycER protein enabled cells to enter and stay in the cell cycle, demonstrating that Myc activity is dominant over p53-mediated $\mathrm{G}_{1}$ growth arrest (Fig. 4 and

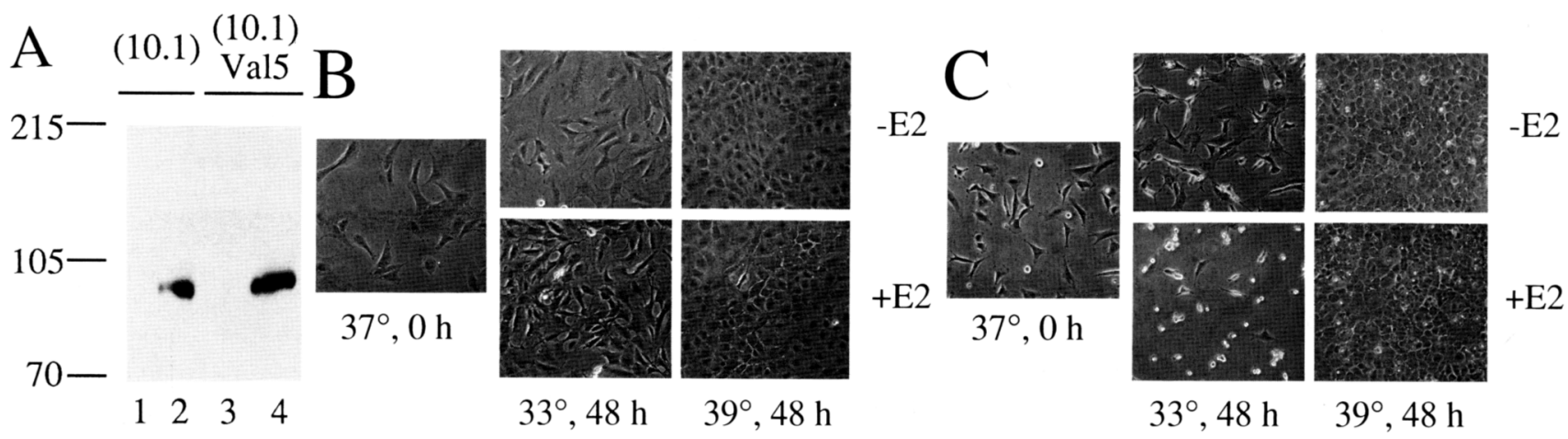

Figure 2. Effects of Myc and p53 on cell phenotypes. $(A)$ Western analysis of MycER expression in $(10.1)$ and $(10.1)$ Val5 cells. Extracts from $2 \times 10^{5}$ cells were electrophoresed in an $8 \%$ SDS-polyacrylamide gel and analyzed as in Fig. 1. (Lanes 1,3) Lysates from (10.1) and (10.1)Val5 cells infected with the control pMV12 virus; (lanes 2,4) lysates from (10.1) and (10.1)Val5 cells infected with the MycER virus, displaying the $90-\mathrm{kD}$ MycER fusion protein. Migrations of molecular mass standards (in kilodaltons) are shown at left. (B) Effect of E2 and temperature shift on phenotypes of $(10.1)$ MycER cells. Pictured are cells $48 \mathrm{hr}$ after temperature shift from $37^{\circ} \mathrm{C}$ to $33^{\circ} \mathrm{C}$ or $39^{\circ} \mathrm{C}$ in the absence $(-\mathrm{E} 2)$ or presence $(+\mathrm{E} 2)$ of $1 \mu \mathrm{M} \mathrm{E} 2 .(\mathrm{C})$ Effect of E2 and temperature shift on phenotypes of $(10.1) \mathrm{Val} 5 \mathrm{MycER}$ cells. Cells were treated as described in $B$. 


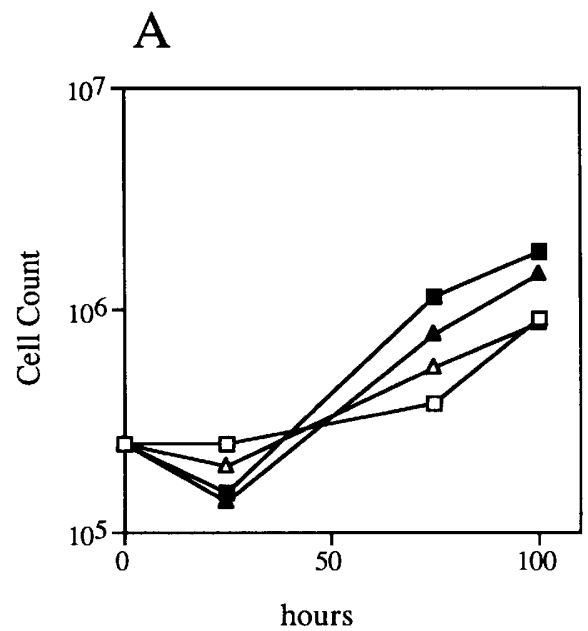

B

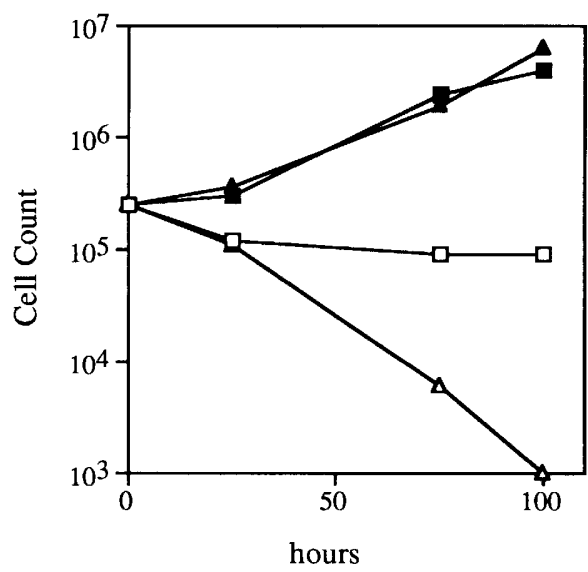

Figure 3. Growth curves following temperature shift and E2 treatment. (A) Numbers of (10.1) MycER cells after various times at $33^{\circ} \mathrm{C}$ (open symbols) and $39^{\circ} \mathrm{C}$ (filled symbols) in the absence (squares) or presence (triangles) of E2. $(B)$ Numbers of (10.1)Val5 MycER cells after various times at $33^{\circ} \mathrm{C}$ (open symbols) and $39^{\circ} \mathrm{C}$ (filled symbols) in the absence (squares) or presence (triangles) of E2.

Table 1). However, as shown in Figure 2C, cell death was readily observable in the (10.1) Val5 MycER cells following treatment with $\mathrm{E} 2$ at the permissive temperature but not at the restrictive temperature. Untreated cells, as described above, were growth arrested at $33^{\circ} \mathrm{C}$ but not at $39^{\circ} \mathrm{C}$. No growth arrest or increase in cell death was observed in the E2-treated (10.1) MycER cells at either temperature (Figs. $2 \mathrm{~B}$ and $3 \mathrm{~A}$ ). Taken together, these data demonstrate that although ectopically expressed Myc overrides p53-induced $G_{1}$ arrest, it also leads to cell death. Induction of this pathway requires both high levels of Myc expression and the expression of wild-type $\mathrm{p} 53$, indicating that $\mathrm{p} 53$ activity is required for susceptibility to Myc-mediated apoptosis.

To verify that cell death was occurring by apoptosis, genomic DNA was prepared from equal numbers of cells

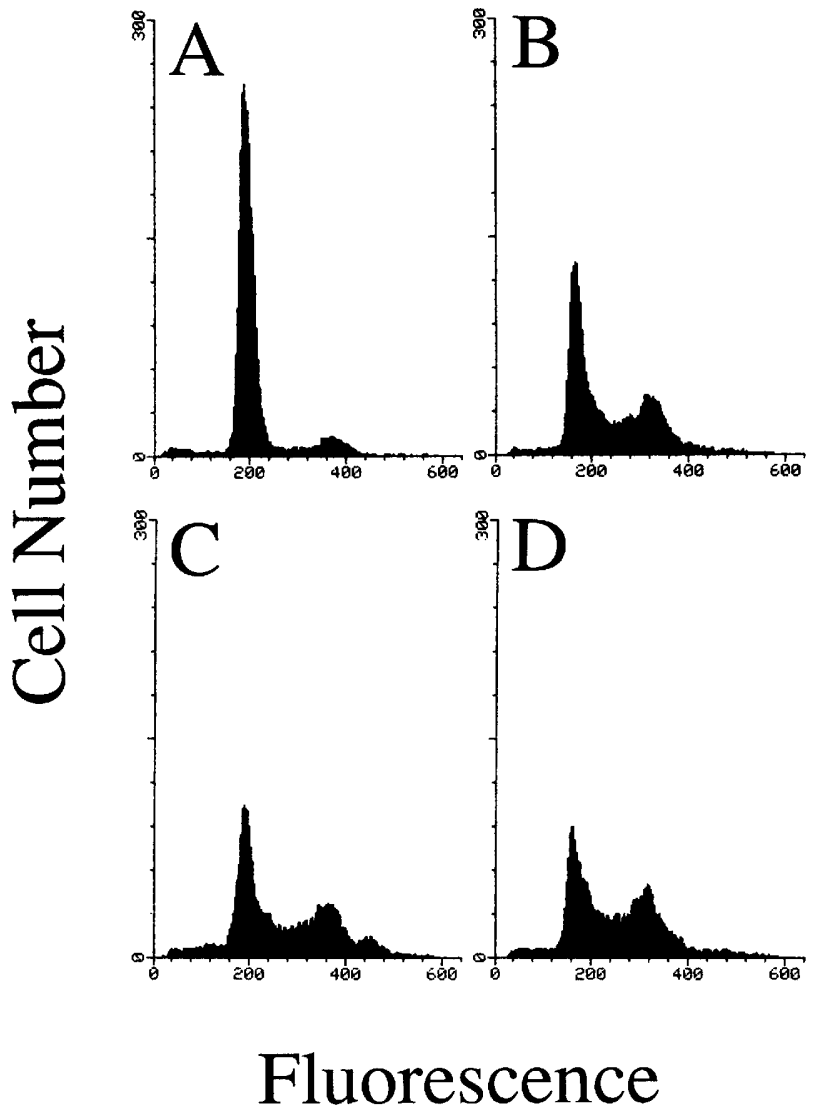

Figure 4. Flow cytometric cell cycle analysis of $(10.1) \mathrm{Val} 5$ MycER cells. Cells were incubated for $48 \mathrm{hr}$ at in the absence $(A, B)$ or presence $(C, D)$ of $\mathrm{E} 2$ at $33^{\circ} \mathrm{C}(A, C)$ or $39^{\circ} \mathrm{C}(B, D)$, then fixed, stained with propidium iodide, and analyzed by flow cytometry. DNA content is represented by relative fluorescence. Cells in $G_{0} / G_{1}$ are represented by the first peak, cells in $G_{2} / M$ are represented by the second peak, and cells in $S$ are represented by the area between the peaks. Quantitation of cell cycle distributions is presented in Table 1.

that had been treated for $48 \mathrm{hr}$ at $33^{\circ} \mathrm{C}$ or $39^{\circ} \mathrm{C}$ in the presence or absence of E2. Agarose gel electrophoresis of this DNA demonstrated the oligonucleosomal fragmentation pattern characteristic of apoptotic cell death only in cells expressing wild-type p53 with active Myc (Fig.

Table 1. Cell cycle distribution of (10.1)Val5 MycER cells following temperature shift and addition of E2

\begin{tabular}{llll}
\hline Conditions & $\begin{array}{l}\text { Percent } \\
\mathrm{G}_{0} / \mathrm{G}_{1}\end{array}$ & \multicolumn{1}{l}{ Percent } & $\begin{array}{l}\text { Percent } \\
\mathrm{G}_{2} / \mathrm{M}\end{array}$ \\
\hline $33^{\circ} \mathrm{C}$ & $83.4 \pm 4.3$ & $6.5 \pm 1.0$ & $10.2 \pm 4.5$ \\
$33^{\circ} \mathrm{C}+\mathrm{E} 2$ & $50.4 \pm 4.8$ & $16.8 \pm 6.8$ & $32.8 \pm 4.4$ \\
$39^{\circ} \mathrm{C}$ & $59.8 \pm 9.6$ & $19.3 \pm 4.3$ & $20.7 \pm 6.4$ \\
$39^{\circ} \mathrm{C}+\mathrm{E} 2$ & $46.3 \pm 4.5$ & $24.7 \pm 4.0$ & $28.4 \pm 6.7$
\end{tabular}

Values represent means \pm S.E. of triplicate measurements of cell cycle distribution determined by flow cytometry. A representative analysis is presented in Fig. 4. 
5A). This was observed in both the floating cells and, to a lesser extent, the adherent cells. The apoptosis in the adherent cells was more readily detectable by a sensitive method that involves end-labeling DNA fragment termini with $\left[{ }^{32} \mathrm{P}\right] \mathrm{ddATP}$ by terminal deoxynucleotidyl transferase (Tilly and Hsueh 1993) followed by agarose gel electrophoresis (Fig. 5B). Even at longer exposures, at most minimal fragmentation was observed in other cell lines or conditions (data not shown).

Cells growth-arrested by amino acid starvation but not expressing wild-type p53 are refractory to Myc-mediated apoptosis

Because wild-type p53 expression in these cells led to growth arrest, and because other means of growth arrest in cells with normal levels of wild-type p53 resulted in susceptibility to Myc-mediated apoptosis (Evan et al. 1992), we wondered whether growth arrest was sufficient or whether p53 itself was specifically required for this process. Accordingly, we arrested (10.1)Val5 MycER cells in a manner independent of p53. As shown in Figure $6 \mathrm{~A}$ and Table 2 , cells expressing mutant p53 were arrested in $G_{1}$ by isoleucine deprivation. After treatment with E2, no significant cell death was observed even after $60 \mathrm{hr}$ of starvation (Fig. 6B). However, in cells placed at $33^{\circ} \mathrm{C}$, with p53 in its native conformation, or in Rat la cells, which express wild-type p53 (see below), the activation of MycER led to cell death within $24 \mathrm{hr}$ (Fig.

A

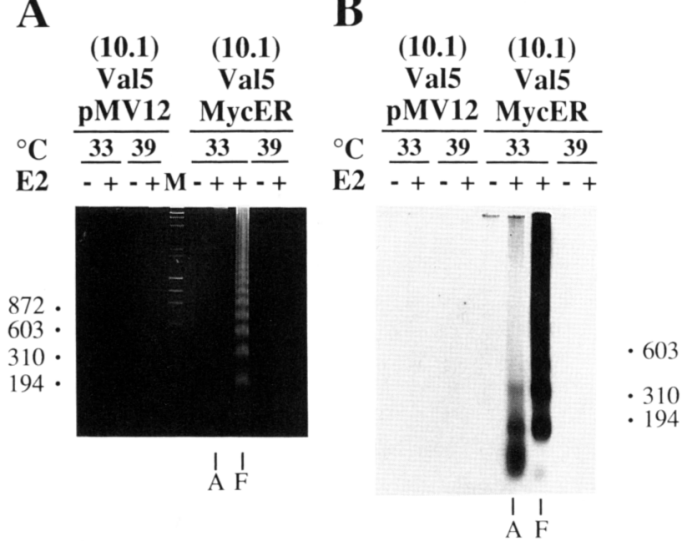

Figure 5. DNA fragmentation analysis. Genomic DNA was prepared from (10.1)Val5 pMV12 and (10.1)Val5 MycER cells 48 hr after temperature shift to $33^{\circ} \mathrm{C}$ or $39^{\circ} \mathrm{C}$ and treatment with E2, as indicated. $(A)$ Ethidium bromide-stained $2 \%$ agarose gel containing DNA from approximately $4 \times 10^{5}$ cells per lane. Adherent $(A)$ and floating $(F)$ cells were separated only in the analysis of (10.1)Val5 MycER cells at $33^{\circ} \mathrm{C}$ with $\mathrm{E} 2$, as these were the only cells with significant numbers of floating cells. Migrations of restriction digested $\lambda$ and $\phi \mathrm{X} 174$ molecular size standards (in base pairs) are shown. (B) Agarose gel electrophoresis of $100 \mathrm{ng}$ of genomic DNA prepared from cells treated as indicated. DNA fragment termini were end-labeled with $\left[{ }^{32} \mathrm{P}\right]$ ddATP by terminal deoxynucleotidyl transferase prior to electrophoresis. Positions of molecular size standards are indicated.
6C,D). The absence of cell death in E2-treated cells at $39^{\circ} \mathrm{C}$ is not attributable to a gain-of-function property of mutant p53 because (10.1) MycER cells, which do not express detectable levels of p53 (Harvey and Levine 1991, and see below) were also refractory to Myc-mediated apoptosis following isoleucine starvation (data not shown). Therefore, $G_{1}$ growth arrest per se is not sufficient for susceptibility to Myc-mediated apoptosis; rather, a property intrinsic to p53 is specifically required.

p53-dependent induction of protein synthesis, including induction of $p 21^{\text {wafl/cip } 1}$, is not required for apoptosis

p53 is thought to function at least in part through its ability to regulate transcription. Its ability to cause $G_{1}$ arrest is dependent on transcriptional activation domains at the amino terminus of the protein (Pietenpol et al. 1994). p53 has been demonstrated to induce expression of a recently identified protein, $\mathrm{p} 21^{\text {waf1/cip1 }}$ (ElDeiry et al. 1993) that inhibits cdk activity and therefore is able to elicit cell cycle arrest (Harper et al. 1993; Xiong et al. 1993; Dulic et al. 1994). To address the possibility that Myc-mediated apoptosis is induced by an intrinsic property of $\mathrm{p} 53$ that is independent of its ability to cause growth arrest, we examined whether p53-dependent apoptosis required new protein synthesis. Apoptosis was measured by analyzing DNA fragmentation, which precedes loss of viability and allows for analysis prior to toxicity from long term cycloheximide ( $\mathrm{CHX}$ ) treatment. (10.1)Val5 MycER cells were grown at the restrictive temperature with E2 present in the media for $6 \mathrm{hr}$ prior to temperature shift. CHX was added to the media $1 \mathrm{hr}$ prior to temperature shift to block synthesis of p53-inducible proteins following placement of the cells at the permissive temperature. As shown in Figure 7A, DNA fragmentation was induced to similar levels in cells at the permissive temperature treated with $\mathrm{E} 2$ in the presence or absence of CHX. Low levels of fragmentation were observed in untreated cells or cells treated with CHX alone because of leakiness of MycER ${ }_{i}$ however, DNA fragmentation was not observed in cells treated in any of the conditions at the restrictive temperature. This is also consistent with previous observations that $\mathrm{CHX}$ treatment does not affect Myc-mediated apoptosis in Rat 1 cells (Evan et al. 1992, and A.J. Wagner and H. Hay, unpubl.). This regimen of $\mathrm{CHX}$ treatment blocked induction of $\mathrm{p} 21^{\text {waf1/cip } 1}$, otherwise detectable $4 \mathrm{hr}$ after temperature shift, as shown by Western analysis (Fig. 7B).

\section{Established cell lines expressing wild-type p53 can be resistant to Myc-mediated apoptosis}

In our studies of Myc-mediated apoptosis in fibroblasts, we noticed that although Rat la cells, mouse and rat embryo fibroblasts, and WI-38 cells were highly susceptible, other fibroblast cell lines, including BALB/c 3T3 (A31) cells, were not (A.J. Wagner and N. Hay, unpubl.). We wondered whether this may be attributable, at least in part, to the status of p53 in these cells. Accordingly, 


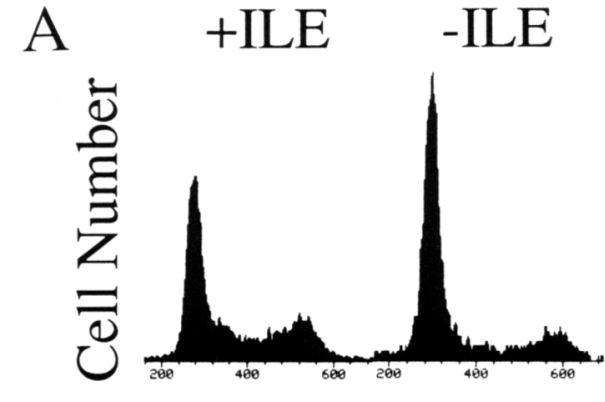

Fluorescence

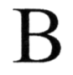

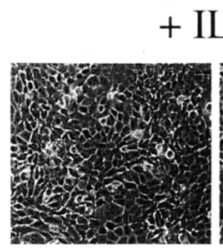

-E2
ILE

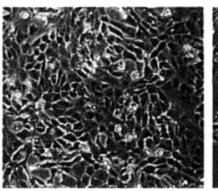

$+\mathrm{E} 2$

D
- ILE

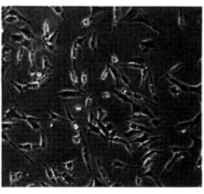

$-\mathrm{E} 2$

- ILE
+ ILE

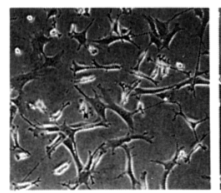

$-\mathrm{E} 2$

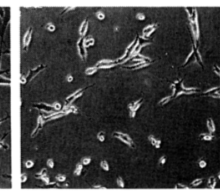

$+\mathrm{E} 2$ - ILE

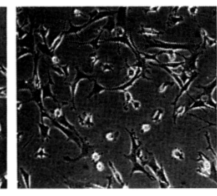

$-\mathrm{E} 2$

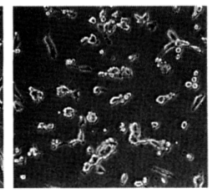

$+\mathrm{E} 2$

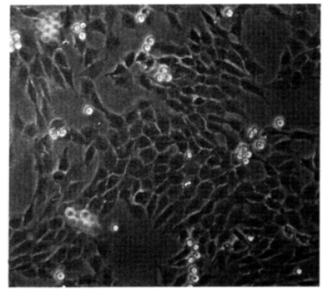

$-\mathrm{E} 2$

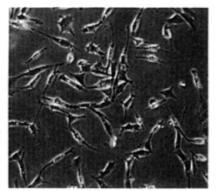

$+\mathrm{E} 2$

Figure 6. Effect of amino acid starvation on susceptibility to Myc-mediated apoptosis. $(A)$ Isoleucine starvation causes $\mathrm{G}_{1}$ arrest in (10.)Val5 MycER cells independently of p53. Cells were incubated at the restrictive temperature in normal DMEM (+ILE) or isoleucine-free DMEM (-ILE) for $60 \mathrm{hr}$ and analyzed as described in Fig. 4. Quantitation is presented in Table 2. (B) Effect of MycER activation in isoleucine-starved $(10.1)$ Val5 MycER cells at the restrictive temperature. Cells $\left(10^{6}\right)$ were grown at $39^{\circ} \mathrm{C}$ and photographed $60 \mathrm{hr}$ after treatment with E2 in normal or isoleucine-free media, as indicated. Note growth to confluency in normal media but arrest without cell death in isoleucine-free media, regardless of addition of E2. $(C)$ Cells treated as in $B$ but at the permissive temperature $\left(33^{\circ} \mathrm{C}\right)$. Note growth arrest in untreated cells in presence or absence of isoleucine, and prominent cell death in normal or deficient media after treatment with E2. (D) Myc-induced cell death following isoleucine starvation of cells with endogenous wild-type p53. Rat la MycER cells were starved of isoleucine and treated with E2 for $60 \mathrm{hr}$, as indicated.

we immunoprecipitated $\mathrm{p} 53$ from $\left[{ }^{35} \mathrm{~S}\right]$ methionine metabolically labeled cells to identify, using conformationspecific antibodies, whether indeed p53 was wild type in Rat la cells yet mutant in the resistant cell lines. On the basis of its immunoprecipitation with pan- and wildtype- but not mutant-specific antibodies /Harlow et al. 1981; Tan et al. 1986; Yewdell et al. 1986; Gannon et al. 1990 ), we found that Rat 1a cells expressed only wildtype p53 (Fig. 8). By the same criteria we observed that $\mathrm{BALB} / \mathrm{c}$ 3T3 (A31) cells also expressed only wild-type

Table 2. Cell cycle distribution of (10.1)Val5 MycER cells

\begin{tabular}{llrl}
\hline Conditions & $\begin{array}{l}\text { Percent } \\
\mathrm{G}_{0} / \mathrm{G}_{1}\end{array}$ & \multicolumn{1}{c}{$\begin{array}{l}\text { Percent } \\
\mathrm{S}\end{array}$} & \multicolumn{1}{l}{$\begin{array}{l}\text { Percent } \\
\mathrm{G}_{2} / \mathrm{M}\end{array}$} \\
\hline - ILE & $81.7 \pm 3.8$ & $5.9 \pm 2.6$ & $12.2 \pm 1.6$ \\
+ILE & $55.9 \pm 4.5$ & $22.4 \pm 1.4$ & $22.8 \pm 4.8$ \\
\hline
\end{tabular}

Distribution of cells after $60 \mathrm{hr}$ of isoleucine starvation (-ILE) or growth in normal media ( ILE).

Values represent means \pm S.E. of triplicate measurements of cell cycle distribution determined by flow cytometry. A representative analysis is presented in Fig. 6A. p53, as was reported previously /Gronostajski et al. 1984). In addition, we have isolated revertants of Rat 1a cells that are still transformed by Myc and express wildtype p53 yet are no longer susceptible to Myc-induced cell death (A.J. Wagner and N. Hay, unpubl.). Thus, although wild-type p53 is required for apoptosis induced by Myc deregulation, it is not sufficient, and other lesions apparently may also block the cell death pathway.

\section{Discussion}

We introduced constitutively or conditionally active alleles of c-Myc into cells that do not express p53 to evaluate the role of wild-type p53 activity in Myc-induced apoptosis. Under conditions of serum starvation, which elicits apoptosis when Myc is overexpressed in primary cells and some established cell lines with wild-type p53 (Evan et al. 1992), these cells did not undergo cell death. Introduction of a conditional p53 allele resulted in susceptibility to cell death only in conditions in which p53 was in its wild-type conformation and Myc was active. Although wild-type p53 induced cell cycle arrest in cells (in the absence of active Myc), growth arrest by p53- 


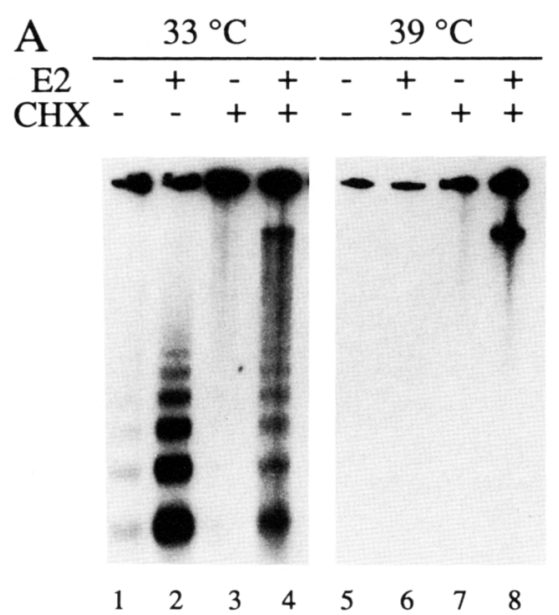

B

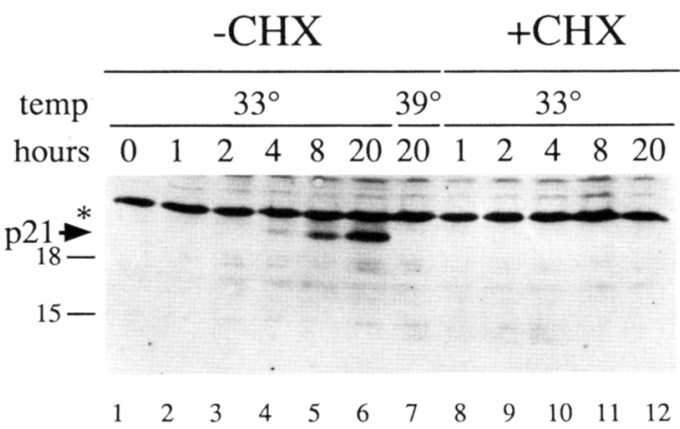

Figure 7. Induction of apoptosis independent of p53-mediated protein synthesis. (A) Agarose gel electrophoresis of end-labeled genomic DNA. Cells [10.1/Val5 MycER] were grown at $39^{\circ} \mathrm{C}$ and treated with E2 as indicated for $6 \mathrm{hr}$ prior to temperature shift. One hour before temperature shift, cells, as indicated, were treated with $15 \mu \mathrm{g} / \mathrm{ml} \mathrm{CHX}$. Cells were then shifted to $33^{\circ} \mathrm{C}$ or left at $39^{\circ} \mathrm{C}$. Genomic DNA was prepared from cells 16 hr after temperature shift and labeled as described in Fig. 5B. (Lanes 1,5) No treatment; (lanes 2,6) E2 alone; (lanes 3,7) CHX alone; (lanes 4,8) E2 and CHX. $(B)$ Western analysis of p21 expression following temperature shift of (10.1)Val5 MycER cells in presence or absence of $15 \mu \mathrm{g} / \mathrm{ml}$ of CHX. Whole-cell lysates were prepared from cells various times after shift from $39^{\circ} \mathrm{C}$ to $33^{\circ} \mathrm{C}$ and analyzed by electrophoresis through a $12.5 \%$ SDSpolyacrylamide gel. After transfer to nitrocellulose, $\mathrm{p} 21$ was detected by incubation with a rabbit anti-p21 polyclonal antibody (PharMingen) followed by ECL. The positions of $\mathrm{p} 21$ and protein molecular size standards (in kilodaltons) are indicated. The asterisk (*) indicates a protein nonspecifically recognized by the primary antibody. (Lanes 1-6) Lysates from cells after temperature shift to $33^{\circ} \mathrm{C}$ for various times, as indicated; (lane 7) control lysate from cells not temperature-shifted; (lanes 8-12) lysates from cells treated with CHX beginning $1 \mathrm{hr}$ prior to temperature shift.

independent means was not sufficient to make cells susceptible to Myc-mediated apoptosis. From these observations, we conclude that, at least in fibroblasts, functional p53 is required for apoptosis induced by Myc.

It is important to emphasize that although wild-type p53 is required for Myc-induced cell death, other factors may override this pathway. Therefore, cells that express wild-type p53 may not always be susceptible to Mycmediated apoptosis. This is demonstrated clearly in cells in which a dominant survival protein, such as Bcl-2, is expressed. For instance, Rat la cells, which express wildtype p53 (see above), are highly susceptible to Myc-induced apoptosis, but ectopic expression of $\mathrm{Bcl}-2$, the Bcl2-like protein Bcl- $\mathrm{x}_{\mathrm{L}}$ (Boise et al. 1993), or adenovirus E1B 19K protein will override the induction of cell death (Fanidi et al. 1992; Wagner et al. 1993b, and A.J. Wagner and N. Hay, unpubl.). Thus, expression of a survival gene will block apoptosis, even in the presence of wild-type p53.

Curiously, BALB/c 3T3 (A31) murine fibroblasts, which express wild-type p53 (Gronostajski et al. 1984, and see above), are not susceptible to Myc-mediated apoptosis when starved of serum growth factors (A.J. Wagner and N. Hay, unpubl.). In this cell line, the p53-dependent apoptosis pathway has apparently been uncoupled from p53 expression, although the precise mechanism for how this occurred has yet to be determined. It is interesting to note that $\mathrm{BALB} / \mathrm{c} 3 \mathrm{~T} 3$ (A31) cells are exceptional in that 11 of 11 clonal fibroblast cell lines established from BALB/c embryos by a $3 \mathrm{~T} 3$ passage schedule mutated or deleted p53 during the course of immortalization (Harvey and Levine 1991). The genetic lesion(s) that occurred during BALB/c 3T3 (A31) immortalization may also account for its resistance to Mycmediated apoptosis. In addition, we have isolated Rat la revertants that are no longer susceptible to Myc-mediated apoptosis yet still express wild-type p53 (A.J. Wagner and N. Hay, unpubl.).

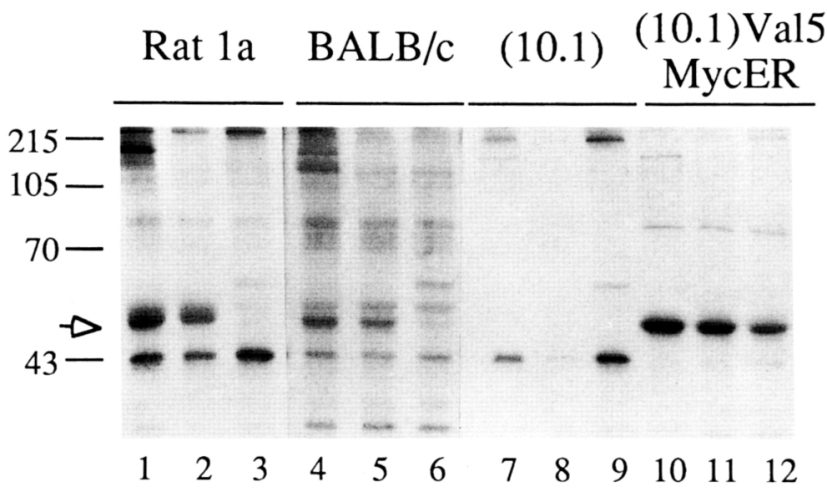

Figure 8. Immunoprecipitation of p53 from various cell lines. Rat la, BALB/c 3T3 (A31), (10.1), and (10.1) Val5 MycER cells were labeled with $\left[{ }^{35} \mathrm{~S}\right]$ methionine, and $\mathrm{p} 53$ proteins were immunoprecipitated with monoclonal antibodies from cell lysates. Precipitates were denatured in $2 \times$ sample buffer and analyzed by $10 \%$ SDS-PAGE followed by fluorography. Lanes represent proteins immunoprecipitated with PAb421 (Ab-1, Oncogene Science), a pan-specific anti-p53 antibody (lanes $1,4,7,10)$, PAb246 (Ab-4), a wild-type-specific anti-p53 antibody (lanes 2,5,8,11), or PAb240 (Ab-3), a mutant-specific anti-p53 antibody (lanes $3,6,9,12$ ). The position of the immunoreactive p53 species is indicated by an arrow, and migrations of molecular size standards are marked. 
A large percentage of human tumors with Myc deregulation exhibit mutations or deletions of p53 or overexpress Bcl-2 or Bcl-2-like proteins. In a survey of hematopoietic malignancies, tumors were found to have either p53 mutations or Bcl-2 overexpression but not both (Gaidono et al. 1991). This may reflect the common path in which these genes act so that there is no selective advantage to interfere with both mechanisms. Moreover, p53 mutations are frequently associated with tumor progression (Fearon and Vogelstein 1990; Sidransky et al. 1992; Kemp et al. 1993), perhaps reflecting a diminishment of tumor cell death due to apoptosis.

Our results show that $\mathrm{p} 53$ is specifically required for Myc-induced apoptosis. This is consistent with previous reports in which functional p53 is required for apoptosis induced by a variety of means in several systems. Wildtype p53 has been shown to be required for irradiationinduced apoptosis of thymocytes and for irradiation- and chemotherapeutic agent-induced apoptosis in fibroblasts sensitized by adenovirus E1A expression (Lowe et al. $1993 \mathrm{a}, \mathrm{b})$. Furthermore, reintroduction of p53 into tumor cell lines with mutant or null p53 can induce apoptosis. For example, after reintroduction of p53 into a v-Mycinduced $\mathrm{T}$ cell lymphoma or into a Burkitt lymphoma, apoptosis may result from overexpression of Myc in the presence of wild-type p53 (Ramqvist et al. 1993; Wang et al. 1993a). Introduction of wild-type p53 into a myeloid tumor cell line, a colon cancer cell line, and murine erythroid leukemia cells also resulted in apoptosis (Yonisch-Rouach et al. 1991; Shaw et al. 1992; Johnson et al. 1993), which may be a reflection of oncogene deregulation in these cells.

Despite the dependence of multiple forms of apoptosis on functional p53, p53 is not required for all forms of apoptosis, because phorbol ester or glucocorticoid treatment of thymocytes induces cell death even in a p53 null background (Clarke et al. 1993). In addition, androgen ablation in p53-null mice does not affect involution of the prostate (Berges et al. 1993), which has been shown to be a result of apoptosis. These examples suggest that there are multiple paths to this form of cell death. Interestingly, Bcl-2 overexpression can block both p53-dependent and p53-independent means of apoptosis, suggesting that it acts downstream of a putative junction of p53-dependent and p53-independent pathways (Alnemri et al. 1992; Fanidi et al. 1992; Lotem and Sachs 1993; Wagner et al. 1993b; Wang et al. 1993b; Chou et al. 1994; Reed 1994).

\section{How does Myc induce apoptosis?}

Myc can act as a sequence-specific transcriptional activator and directly induce the expression of certain genes (Benvenisty et al. 1992; Kretzner et al. 1992; Amin et al. 1993; Bello-Fernandez et al. 1993; Jansen-Dürr et al. 1993; Reisman et al. 1993; Wagner et al. 1993a). In addition, Myc can specifically suppress the expression of other genes (Freytag and Geddes 1992; Roy et al. 1993; Philipp et al. 1994). The ability of Myc to induce apoptosis requires dimerization with Max (Amati et al. 1993) and the amino terminus of Myc (Evan et al. 1992), which contains domains necessary for transcriptional activation (Kato et al. 1990; Amin et al. 1993). Despite these observations suggesting transcriptional activation by Myc is a component of its ability to induce apoptosis, Myc-mediated apoptosis is not inhibited by CHX (Evan et al. 1992; A.J. Wagner and N. Hay, unpubl.), indicating that de novo protein synthesis is not essential. One possible explanation is that synthesis of a protein(s) induced by Myc and required for apoptosis escapes $\mathrm{CHX}$ inhibition. Other intriguing possibilities, such as direct suppression of survival genes by Myc, intimate association of Myc with DNA repair or replication machinery, or induction of noncoding RNAs capable of mediating apoptosis [as shown for tumor suppression (Hao et al. 1993; Rastinejad et al. 1993)], are conceivable.

Regardless of the mechanism by which Myc induces apoptosis, this pathway can be blocked by growth factors present in serum [IGF-1, in particular (Harrington et al. 1994)] and by survival genes such as bcl-2. The expression of at least one gene, $p 53$, is required for the induction of this apoptotic pathway, as demonstrated by the studies presented in this report. In this respect, Mycmediated apoptosis resembles apoptosis induced by the viral oncogene E1A. This protein stabilizes p53 (Lowe and Ruley 1993|, which in turn may lead to apoptosis that can be blocked by coexpression of E1B (Debbas and White 1993). Although it was reported that Myc can induce transcription from the p53 promoter in transient transfection assays (Reisman et al. 1993), we could not demonstrate significant induction of endogenous p53 mRNA or protein following activation of MycER in serum-starved Rat la cells in conditions that lead to induction of ornithine decarboxylase (ODC) expression and activity and induction of cell death (Wagner et al. 1993a; A.J. Wagner and N. Hay, unpubl.). We therefore conclude that in the absence of growth factors the normal level of p53 within these cells is sufficient to confer susceptibility to Myc-mediated apoptosis. This is consistent with the observation that CHX does not block the induction of apoptosis by Myc. High levels of constitutively expressed wild-type p53, however, confer susceptibility to Myc-mediated apoptosis even in the presence of growth factors, as shown with (10.1)Val5 MycER cells.

\section{How does p53 confer susceptibility to Myc-mediated apoptosis?}

Wild-type p53 functions as a negative regulator of cell cycle progression. As discussed above, wild-type p53 can also deliver an apoptosis signal induced by a variety of cell death stimuli. At the molecular level, wild-type p53 can both activate transcription of genes through its sequence-specific DNA-binding site (Kastan et al. 1992; El-Deiry et al. 1993; Juven et al. 1993) or suppress transcription of genes that do not contain its binding site, probably through its interaction with the TATA-binding protein (Ginsberg et al. 1991; Mack et al. 1993; Ragimov et al. 1993). The function of wild-type p53 as a transcriptional activator is tightly linked to its ability to arrest 
cell cycle progression (Zambetti and Levine 1993; Pietenpol et al. 1994). In particular, p53 is thought to elicit growth arrest by direct induction of expression of p21 ${ }^{\text {waf1/cip1 }}$ (El-Deiry et al. 1993), a cdk inhibitor (Harper et al. 1993; Xiong et al. 1993; Dulic et al. 1994). The inhibition of cdks leads to cell cycle arrest, in part by preventing hyperphosphorylation of $\mathrm{pRb}$ (Pines and Hunter 1991; Reed 1992).

One possibility for how this could lead to cell death, which was suggested for E1A and E2F-mediated apoptosis, is that growth arrest signals induced by p53, at least in part by its direct induction of $\mathrm{p} 21^{\text {waf } 1 / \text { cip } 1}$ expression, conflict with the growth stimulus provided by Myc expression and together these signals combine to initiate a cell death cascade (Wu and Levine 1994). However, our results in conjunction with those of others raise the possibility that the abilities of p53 to induce growth arrest and to mediate apoptosis may not necessarily be coupled. First, Myc-mediated apoptosis is dependent on the presence of wild-type p53 yet does not require induction of new protein synthesis, including $\mathrm{p} 21^{\text {waf } 1 / \text { cip } 1}$, by $\mathrm{p} 53$. This is consistent with previous results demonstrating that p53-induced apoptosis is uncoupled from p53-induced growth arrest (Yonish-Rouach et al. 1993), as well as with recent observations of Karin and colleagues indicating that UV irradiation-induced apoptosis is dependent on the presence of wild-type p53 and does not require transcriptional activation by p 53 (Caelles et al. 1994). Second, isoleucine starvation, which leads to growth arrest, is capable of eliciting Myc-mediated apoptosis even in the presence of serum growth factors. It was shown that isoleucine starvation arrests cells in the $\mathrm{G}_{1}$ phase of the cell cycle at least in part by dephosphorylation of $\mathrm{pRB}$, even when $\mathrm{p} 53$ is sequestered by SV40 large T antigen (Münger et al. 1992). Our results demonstrate that cells that are null for wild-type p53 are refractory to Myc-mediated apoptosis elicited by isoleucine starvation. Thus, even in cells that are growth arrested in a p53-independent manner, functional p53 is still required for susceptibility to Myc-mediated apoptosis. This supports the notion that the role of $\mathrm{p} 53$ in apoptosis is distinct from its function in growth arrest. Finally, Myc can override the growth-arresting properties of p53 (see Fig. 4 and Table 1), arguing that a pathway towards apoptosis is separate from growth arrest because even cells overexpressing wild-type p53 are not arrested in the presence of deregulated Myc.

Taken together these results strongly suggest that the function of wild-type p53 in apoptosis is not tightly linked to its function in cell cycle arrest. Whether wildtype p53 itself serves as an intermediate player in the apoptotic pathway or plays an indirect role by suppression of survival genes remains to be elucidated.

\section{Materials and methods}

\section{Retroviruses}

To construct pMV12-MycER, the EcoRI fragment of pMV7MycER (Eilers et al. 1989) was cloned into a partial EcoRI di- gestion of pMV12 (Cacace et al. 1993) such that the MycER fusion gene was inserted between the $5^{\prime}$ long terminal repeat and the thymidine kinase promoter/hygromycin phosphotransferase cassette. A DNA/lipofectamine (GIBCO/BRL) mixture was transfected into $\Psi 2$ cells and retroviruses were prepared as described previously (Wagner et al. 1993b). Virus from the conditioned media of the $\Psi 2$ pMV12-MycER cells was used to infect PA317 cells to produce amphotropic viruses, as described previously (Wagner et al. 1993b).

\section{Cell culture}

All cell lines were maintained in Dulbecco's modified Eagle medium (DMEM) with $10 \%$ fetal bovine serum (FBS; with certified low estrogen content, GIBCO/BRL) in a humidified atmosphere with $5 \% \mathrm{CO}_{2}$. Cells expressing ER-fusion proteins were maintained in media without phenol red (GIBCO/BRL).

MEFs were a gift of L. Donehower (Baylor College of Medicine, Houston, TX) and were prepared from 14.5-day C57/B6 embryos with homozygous inactivation of both p53 genes or from normal littermates, as described (Harvey et al. 1993). Wildtype or $p 53^{-1-}$ MEFs (at passage 5 or earlier) were infected with pMV12, pMV12-Myc, or pMV12-MycER retroviruses and selected in $400 \mu \mathrm{g} / \mathrm{ml}$ of hygromycin B (Calbiochem) for $48 \mathrm{hr}$ and then maintained in $200 \mu \mathrm{g} / \mathrm{ml}$ hygromycin $\mathrm{B}$. We were repeatedly unable to establish hygromycin-resistant wild-type MEFs constitutively expressing c-Myc. Wild-type MEFs expressing the MycER fusion protein were successfully established in 50 $\mu \mathrm{g} / \mathrm{ml}$ of hygromycin B but could not be maintained as a cell line. Similar difficulties have been reported in establishing ElAexpressing MEF cell lines (Lowe et al. 1993a).

(10.1) and (10.1) Val5 cells (kindly provided by A.J. Levine, Princeton University, NJ/ are immortalized mouse fibroblast cell lines from BALB/c mice (Harvey and Levine 1991; Wu et al. 1993). The (10.1) clone spontaneously deleted large portions of both p53 alleles during immortalization and does not express detectable p53; $(10.1)$ Val5 is a derivative of (10.1) expressing a temperature-sensitive $\mathrm{p} 53$ protein with a valine for alanine substitution at codon 135 (Michalovitz et al. 1990). These cells were infected with pMV12 or pMV12-MycER retroviruses and selected as described above. Resistant colonies were pooled after 10-14 days of selection.

\section{Induction and analysis of cell death}

Equal numbers of wild-type or $p 53^{-1-}$ MEFs infected with control or Myc-expressing retroviruses were plated in DMEM with $10 \%$ FBS. Twenty-four hours after plating, cells were washed once with phosphate-buffered saline (PBS) and starved of serum in DMEM with $0.1 \%$ FBS. Cells were maintained in these conditions for $72 \mathrm{hr}$ and then photographed. $p 53^{-} 95 /^{-}$MEFs and wild-type MEFs expressing the MycER fusion protein were starved for $24 \mathrm{hr}$ in DMEM/0.1\% FBS and then treated with 1 $\mu \mathrm{M}$ 17ß-estradiol (E2; Sigma). Cells were photographed $72 \mathrm{hr}$ after addition of E2. Cell viability was determined in triplicate by trypan blue exclusion.

(10.1) pMV12, (10.1) MycER, (10.1)Val5 pMV12, and (10.1)Val5 MycER cells were maintained in phenol red-free media at $37^{\circ} \mathrm{C}$. Cells were plated at $10^{6}$ per $100-\mathrm{mm}$-diam. plate and allowed to attach at $37^{\circ} \mathrm{C}$ for $15 \mathrm{hr}$. Cells were then transferred to $33^{\circ} \mathrm{C}$ or $39^{\circ} \mathrm{C}$, and $24 \mathrm{hr}$ after temperature shift, $1 \mu \mathrm{M} \mathrm{E} 2$ was added to plates as indicated in the figure legends. At various times after addition of E2, cells were collected and counted for growth curves, fixed in $70 \% \mathrm{EtOH}$ in PBS as described for flow cytometric analysis (Wagner et al. 1993b), or harvested for DNA 
fragmentation analysis. Identical results were obtained when temperature shift and E2 addition were simultaneous.

For isoleucine-starvation experiments, cells were washed with PBS and refed with isoleucine-deficient RPMI 1640 media (SelectAmine, GIBCO/BRL) containing 10\% dialyzed FBS and incubated at $33^{\circ} \mathrm{C}$ or $39^{\circ} \mathrm{C}$ for $60 \mathrm{hr}$. As indicated, cells were simultaneously treated with $1 \mu \mathrm{M}$ E2.

For CHX experiments, $10^{6}$ cells we plated per $100-\mathrm{mm}$-diam. plate and incubated at $39^{\circ} \mathrm{C}$ for $12 \mathrm{hr}$. Cells were treated with 1 $\mu \mathrm{M}$ E2 (as necessary) starting $6 \mathrm{hr}$ before temperature shift and $15 \mu / \mathrm{ml} \mathrm{CHX}$ was added $1 \mathrm{hr}$ prior to temperature shift to $33^{\circ} \mathrm{C}$. Control plates were left at $39^{\circ} \mathrm{C}$. Sixteen hours after temperature shift, genomic DNA was harvested from the cells and analyzed as described below.

\section{DNA fragmentation analysis}

Total genomic DNA from $5 \times 10^{5}$ cells was prepared by overnight lysis of cells at $37^{\circ} \mathrm{C}$ in $10 \mathrm{~mm}$ Tris $(\mathrm{pH} 8.0), 100 \mathrm{mM} \mathrm{NaCl}$, $25 \mathrm{~mm}$ EDTA ( $\mathrm{pH} 8.0$ ), $0.5 \%$ SDS, and $0.5 \mathrm{mg} / \mathrm{ml}$ of proteinase $\mathrm{K}$. Lysates were extracted twice in 1:1 phenol/chloroform followed by chloroform; then nucleic acids were precipitated in ethanol. RNA was removed by digestion in $100 \mu \mathrm{g}$ of RNase A per milliliter of TE $\langle\mathrm{pH} 7.8\rangle$ for $2 \mathrm{hr}$ at $37^{\circ} \mathrm{C}$. DNA was then purified by two 1:1 phenol/chloroform and one chloroform extraction, ethanol precipitated, and resuspended in $50 \mu \mathrm{l}$ of TE buffer ( $\mathrm{pH}$ 7.5). Twenty microliters of total DNA was electrophoresed in a $1.5 \%$ agarose/TAE gel, stained with ethidium bromide, and photographed.

In addition to ethidium bromide staining, $100 \mathrm{ng}$ of total genomic DNA was end-labeled for $1 \mathrm{hr}$ at $37^{\circ} \mathrm{C}$ by use of terminal deoxynucleotidyl transferase (Boehringer Mannheim) and $\left[\alpha^{-}{ }^{32} \mathrm{P}\right]$ ddATP (3000 Ci/mmole; Amersham) as described previously (Tilly and Hsueh 1993). The reaction was terminated by the addition of EDTA (pH 8.0), to $25 \mathrm{~mm}$ and yeast tRNA to 1 $\mathrm{mg} / \mathrm{ml}$. Labeled DNA was ethanol precipitated, resuspended in TE $(\mathrm{pH} 7.5)$ and electrophoresed in a $2 \%$ agarose/TAE gel. The gel was fixed in $10 \%$ trichloroacetic acid for $30 \mathrm{~min}$, rinsed with $\mathrm{dH}_{2} \mathrm{O}$, and dried under vacuum overnight prior to autoradiography.

\section{Protein analysis}

Total cellular protein from $2 \times 10^{5}$ cells was prepared by lysis in $2 \times$ sample buffer (Laemmli 1970). Lysates were electrophoresed in $8 \%$ or $12.5 \%$ SDS-polyacrylamide gels for MycER and $\mathrm{p} 21$ detection, respectively. After electrophoresis, proteins were electroblotted to nitrocellulose membranes by semidry transfer. Membranes were blocked overnight at $4^{\circ} \mathrm{C}$ in $5 \%$ (wt $/ \mathrm{vol}$ ) nonfat milk in TBST [Tris-buffered saline $(50 \mathrm{mM}$ Tris, $\mathrm{pH} 7.5 ; 150$ $\mathrm{mM} \mathrm{NaCl}$ ) with $0.2 \%$ (vol/vol) Tween-20). For MycER Westerns, blots were probed with $2 \mu \mathrm{g} / \mathrm{ml} \mathrm{H} 222$ rat anti-human ER monoclonal antibody (a gift of G. Greene, University of Chicago) in TBST with $1 \%$ milk for $2 \mathrm{hr}$ at room temperature, then washed 4 times, $15 \mathrm{~min}$ each, in TBST. Membranes were then incubated with $1 \mu \mathrm{g} / \mathrm{ml}$ rabbit anti-rat $\mathrm{Ig}$ (Zymed) and washed as above. For p 21 Westerns, blots were probed with a 1:1000 dilution of rabbit anti-human p21 polyclonal antibody (PharMingen), as described above. Antibody-antigen interactions were detected by incubation with 1:2000 horseradish peroxidase-conjugated goat anti-rabbit IgG antibodies (Zymed) followed by enhanced chemiluminescence (Amersham).

For detection of p53, cells were starved of methionine for 60 min in methionine- and phenol red-free media (SelectAmine, GIBCO/BRL/ containing $2 \%$ dialyzed fetal bovine serum. Cells were metabolically labeled with $200 \mu \mathrm{Ci} / \mathrm{ml}\left[{ }^{35} \mathrm{~S} \mid\right.$ methionine
(Amersham) for $4 \mathrm{hr}$, washed three times in cold phosphatebuffered saline, scraped, pelleted, and lysed on ice in lysis buffer (150 mM NaCl; $50 \mathrm{~mm}$ Tris at $\mathrm{pH} 8.0 ; 5 \mathrm{~mm}$ EDTA; $1 \mathrm{~mm} \mathrm{DTT}$; $1 \% \mathrm{NP}-40 ; 1 \mu \mathrm{g} / \mathrm{ml}$ pepstatin; $1 \mu \mathrm{g} / \mathrm{ml}$ leupeptin; $1 \mathrm{mM}$ PMSF). Lysates were precleared by $60 \mathrm{~min}$ of incubation at $4^{\circ} \mathrm{C}$ with 5 $\mu \mathrm{g} / \mathrm{ml}$ of mouse IgG (Zymed) then $60 \mathrm{~min}$ with protein A-Sepharose (Pharmacia) preloaded with rabbit anti-mouse IgG antibody (Zymed). Proteins interacting nonspecifically were removed by pelleting the protein A-Sepharose beads. Precleared lysates were split into thirds and incubated for $2 \mathrm{hr}$ at $4^{\circ} \mathrm{C}$ with $3 \mu \mathrm{g} / \mathrm{ml}$ of PAb421 (Ab-1, Oncogene Science), a pan-specific anti-p53 antibody, PAb246 (Ab-4), a wild type-specific anti-p53 antibody, or PAb240 (Ab-3), a mutant-specific anti-p53 antibody (Harlow et al. 1981; Tan et al. 1986; Yewdell et al. 1986; Gannon et al. 1990). Lysates were then incubated with preloaded rabbit anti-mouse Ig-protein A-Sepharose complexes and incubated for $60 \mathrm{~min}$ at $4^{\circ} \mathrm{C}$. Immunoprecipitates were washed twice in lysis buffer, once in TSA (10 mM Tris at pH $8.0 ; 140 \mathrm{~mm}$ $\mathrm{NaCl} ; 0.025 \%$ sodium azide), and once in $50 \mathrm{~mm}$ Tris $(\mathrm{pH} 6.8)$, then eluted by incubating for $10 \mathrm{~min}$ at $95^{\circ} \mathrm{C}$ in $2 \times$ sample buffer. After electrophoresis in a 10\% SDS-polyacrylamide gel, the gel was soaked for $30 \mathrm{~min}$ in $1 \mathrm{M}$ sodium salicylate, washed in $\mathrm{dH}_{2} \mathrm{O}$, dried, and exposed to film.

\section{Acknowledgments}

We are extremely grateful to Tonya $\mathrm{M}$. Hennen and Carolina Salinas for excellent technical assistance. We would like to thank Larry Donehower and Arnold J. Levine for their gracious gifts of MEFs and (10.1) and (10.1)Val5 cells, respectively. We also acknowledge Mark Lechner and Arno Helmberg for technical advice, Geoffrey Greene for anti-ER antibodies and advice on their use, and Michael Karin and Gerard Evan for communicating results prior to publication. This work was supported in part by National Institutes of Health (NIH) grant CA58073 and American Cancer Society grant CB-133 (N.H. and J.M.K.), and NIH training grants GM07281 and CA09594 (A.J.W.)

The publication costs of this article were defrayed in part by payment of page charges. This article must therefore be hereby marked "advertisement" in accordance with 18 USC section 1734 solely to indicate this fact.

\section{References}

Alnemri, E.S., T.F. Fernandes, S. Haldar, C.M. Croce, and G. Litwack. 1992. Involvement of $B C L-2$ in glucocorticoid-induced apoptosis of human pre-B-leukemias. Cancer Res. 52: 491-495.

Amati, B., T.D. Littlewood, G.I. Evan, and H. Land. 1993. The c-Myc protein induces cell cycle progression and apoptosis through dimerization with Max. EMBO /. 12: 5083-5087.

Amin, C., A.J. Wagner, and N. Hay. 1993. Sequence-specific transcriptional activation by Myc and repression by Max. Mol. Cell. Biol. 13: 383-390.

Askew, D.S., R.A. Ashmun, B.C. Simmons, and J.L. Cleveland. 1991. Constitutive c-myc expression in an IL-3-dependent myeloid cell line suppresses cell cycle arrest and accelerates apoptosis. Oncogene 6: 1915-1922.

Bello-Fernandez, C., G. Packham, and J.L. Cleveland. 1993. The ornithine decarboxylase gene is a transcriptional target of c-Myc. Proc. Nat1. Acad. Sci. 90: 7804-7808.

Berges, R.R., Y. Furuya, L. Remington, H.F. English, T. Jacks, and J.T. Isaacs. 1993. Cell proliferation, DNA repair, and p53 function are not required for programmed death of prostatic glandular cells induced by androgen ablation. Proc. Natl. 
Acad. Sci. 90: 8910-8914.

Benvenisty, N., A. Leder, A. Kuo, and P. Leder. 1992. An embryonically expressed gene is a target for c-Myc regulation via the c-Myc-binding sequence. Genes \& Dev. 6: 25132523.

Bishop, J.M. 1991. Molecular themes in oncogenesis. Cell 64: $235-248$.

Bissonnette, R.P., F. Exheverri, A. Mahboubi, and D.R. Green. 1992. Apoptotic cell death induced by c-myc is inhibited by bcl-2. Nature 359: 552-554.

Boise, L.H., M. González-Garcia, C.E. Postema, L. Ding, T. Lindsten, L.A. Turka, X. Mao, G. Nuñez, and C.B. Thompson. 1993. $b c l-x$, a $b c l-2$-related gene that functions as a dominant regulator of apoptotic cell death. Cell 74: 597-608.

Cacace, A.M., S.N. Guadagno, R.S. Krauss, D. Fabbro, and I.B. Weinstein. 1993. The epsilon isoform of protein kinase $\mathrm{C}$ is an oncogene when overexpressed in rat fibroblasts. Oncogene 8: 2095-2104.

Caelles, C., A. Helmburg, and M. Karin. 1994. p53-dependent apoptosis is not mediated by transcriptional activation of p53-target genes. Nature 370: 220-223.

Chou, S.-K., L. Rao, and E. White. 1994. Bcl-2 blocks p53-dependent apoptosis. Mol. Cell. Biol. 14: 2556-2563.

Clarke, A.R., C.A. Purdie, D.J. Harrison, R.G. Morris, C.C. Bird, M.L. Hooper, and A.H. Wyllie. 1993. Thymocyte apoptosis induced by p53-dependent and independent pathways. $\mathrm{Na}$ ture 362: 849-852.

Cole, M.D. 1986. The myc oncogene: Its role in transformation and differentiation. Annu. Rev. Genet. 20: 361-384.

Cory, S. 1986. Activation of cellular oncogenes in hematopoietic cells by chromosome translocation. Adv. Cancer Res. 47: 189-234.

Dalla-Favera, R., F. Wong-Staal, and R.C. Gallo. 1982. Onc gene amplification in promyelocytic leukemia cell line HL-60 and primary leukaemic cells of the same patient. Nature 299: 61-63.

Debbas, M. and E. White. 1993. Wild-type p53 mediates apoptosis by ElA, which is inhibited by E1B. Genes \& Dev. 7: 546-554.

Diller, L., J. Kassel, C.E. Nelson, M.A. Gryka, G. Litwak, M. Gebhardt, B. Bressac, M. Ozturk, S.J. Baker, B. Vogelstein, and S.H. Friend. 1990. p53 functions as a cell cycle control protein in osteosarcomas. Mol. Cell. Biol. 10: 5772-5781.

Donehower, L.A., M. Harvey, B.L. Slagle, M.J. McArthur, C.A. Montgomery Jr., J.S. Butel, and A. Bradley. 1992. Mice deficient for p53 are developmentally normal but susceptible to spontaneous tumours. Nature 356: 215-221.

Dulic, V., W.K. Kaufmann, S.J. Wilson, T.D. Tlsty, E. Lees, J.W. Harper, S.J. Elledge, and S.I. Reed. 1994. p53-dependent inhibition of cyclin-dependent kinase activities in human fibroblasts during radiation-induced Gl arrest. Cell 76: 10131023.

Eilers, M., D. Picard, K. Yamamoto, and J. Bishop. 1989. Chimaeras of Myc oncoprotein and steroid receptors cause hormone-dependent transformation of cells. Nature 340: 66-68.

Eilers, M., S. Schrim, and J.M. Bishop. 1991. The MYC protein activates transcription of the $\alpha$-prothymosin gene. EMBO J. 10: $133-141$.

El-Deiry, W.S., T. Tokino, V.E. Velculescu, D.B. Levy, R. Parsons, J.M. Trent, D. Lin, W.E. Mercer, K.W. Kinzler, and B. Vogelstein. 1993. WAF1, a potential mediator of p53 tumor suppression. Cell 75: 817-825.

Evan, G.I. and T.D. Littlewood. 1993. The role of c-myc in cell growth. Curr. Opin. Genet. Dev. 3: 44-49.

Evan, G.I., A.H. Wyllie, C.S. Gilbert, T.D. Littlewood, H. Land, M. Brooks, C.M. Waters, L.Z. Penn, and D.C. Hancock. 1992.
Induction of apoptosis in fibroblasts by c-myc protein. Cell 69: 119-128.

Fanidi, A., E.A. Harrington, and G.I. Evan. 1992. Cooperative interaction between c-myc and $b c l-2$ proto-oncogenes. $\mathrm{Na}$ ture 359: 554-556.

Farrell, P.J., G.J. Allan, F. Shanahan, K.H. Vousden, and T. Crook. 1991. p53 is frequently mutated in Burkitt's lymphoma cell lines. EMBO F. 10: 2879-2887.

Fearon, E.R. and B. Vogelstein. 1990. A genetic model for colorectal tumorigenesis. Cell 61: 759-767.

Freytag, S.O. and T.J. Geddes. 1992. Reciprocal regulation of adipogenesis by Myc and C/EBP $\alpha$. Science 256: 379-382.

Gaidono, G., P. Ballerini, J.Z. Gong, G. Inghirami, A. Neri, E.W. Newcomb, I.T. Magrath, D.M. Knowles, and R. Dalla-Favera. 1991. p53 mutations in human lymphoid malignancies: Association with Burkitt lymphoma and chronic lymphocytic leukemia. Proc. Natl. Acad. Sci. 88: 5413-5417.

Gannon, J.V., R. Greaves, R. Iggo, and D.P. Lane. 1990. Activating mutations in p53 produce a common conformational effect: A monoclonal antibody specific for the mutant form. EMBO J. 9: 1595-1602.

Ginsberg, D., F. Mechta, M. Yaniv, and M. Oren. 1991. Wildtype p53 can down-modulate the activity of various promoters. Proc. Natl. Acad. Sci. 88: 9979-9983.

Gronostajski, R.M., A.L. Goldberg, and A.B. Pardee. 1984. Energy requirements for degradation of tumor-associated protein p53. Mol. Cell. Biol. 4: 442-448.

Gu, W., K. Bhatia, I.T. Magrath, C.V. Dang, and R. Dalla-Favera. 1994. Binding and suppression of the Myc transcriptional activation domain by p107. Science 264: 251-254.

Hao, Y., T. Crenshaw, T. Moulton, E. Newcomb, and B. Tycko. 1993. Tumour-suppressor activity of H19 RNA. Nature 365: 764-767.

Harlow, E., L.V. Crawford, D.C. Pim, and N.M. Williamson. 1981. Monoclonal antibodies specific for Simian Virus 40 tumor antigen. \%. Virol. 39: 861-869.

Harper, J.W., G.R. Adami, N. Wei, K. Keyomarsi, and S.J. Elledge. 1993. The $\mathrm{p} 21 \mathrm{cdk}$-interacting protein Cipl is a potent inhibitor of G1 cyclin-dependent kinases. Cell 75: 805816.

Harrington, E.A., M.R. Bennett, A. Fanidi, and G.I. Evan. 1994. c-Myc-induced apoptosis in fibroblasts is inhibited by specific cytokines. EMBO /. 13: 3286-3295.

Harvey, D.M. and A.J. Levine. 1991. p53 alteration is a common event in the spontaneous immortalization of primary BALB/c murine embryo fibroblasts. Genes \& Dev. 5: 23752385.

Harvey, M., A.T. Sands, R.S. Weiss, M.E. Heigi, R.W. Wiseman, P. Pantazis, B.C. Giovanella, M.A. Tainsky, A. Bradley, and L.A. Donehower. 1993. In vitro characteristics of embryo fibroblasts derived from p53-deficient mice. Oncogene 8: 2457-2467.

Haupt, Y., W. Alexander, G. Barri, S. Klinken, and J. Adams. 1991. Novel zinc finger gene implicated as myc collaborator by retrovirally accelerated lymphomagenesis in E $\mu-m y c$ transgenic mice. Cell 65: 753-763.

Hollstein, M., D. Sidransky, B. Vogelstein, and C.C. Harris. 1991. p53 mutations in human cancers. Science 253: 49-53.

Jansen-Dürr, P., A. Meichle, P. Steiner, M. Pagano, K. Finke, J. Botz, J. Wessbecher, G. Draetta, and M. Eilers. 1993. Differential modulation of cyclin gene expression by MYC. Proc. Natl. Acad. Sci. 90: 3685-3689.

Johnson, P., S. Chung, and S. Benchimol. 1993. Growth suppression of Friend virus-transformed erythroleukemia cells by p53 protein is accompanied by hemoglobin production and is sensitive to erythropoietin. Mol. Cell. Biol. 13: 1456-1463. 
Juven, T., Y. Barak, A. Zauberman, D.L. George, and M. Oren. 1993. Wild type p53 can mediate sequence-specific transactivation of an internal promoter within the $\mathrm{mdm} 2$ gene. Oncogene 8: 3411-3416.

Kastan, M.B., Q. Zhan, W.S. El-Deiry, F. Carrier, T. Jacks, W.V. Walsh, B.S. Plunkett, B. Vogelstein, and A.J. Fornace Jr. 1992. A mammalian cell cycle checkpoint pathway utilizing p53 and GADD45 is defective in ataxia-telangiectasia. Cell 71: 587-597.

Kato, G.J. and C.V. Dang. 1992. Function of the c-Myc oncoprotein. FASEB I. 6: 3065-3072.

Kato, G.J., J. Barrett, M. Villa-Garcia, and C.V. Dang. 1990. An amino-terminal c-myc domain required for neoplastic transformation activates transcription. Mol. Cell. Biol. 10: 59145920.

Kemp, C.J., L.A. Donehower, A. Bradley, and A. Balmain. 1993. Reduction of p53 gene dosage does not increase initiation or promotion but enhances malignant progression of chemically induced skin tumors. Cell 74: 813-822.

Kretzner, L., E.M. Blackwood, and R.N. Eisenman. 1992. Myc and Max possess distinct transcriptional activities. Nature 359: 426-429.

Laemmli, U.K. 1970. Cleavage of structural proteins during the assembly of the head of bacteriophage T4. Nature 227:680685.

Levine, A.J., J. Momand, and C.A. Finlay. 1991. The p53 tumour supressor gene. Nature 351: 453-456.

Lotem, J. and L. Sachs. 1993. Regulation by bcl-2, c-myc, and p53 of susceptibility to induction of apoptosis by heat shock and cancer chemotherapy compounds in differentiationcompetent and -defective myeloid leukemic cells. Cell Growth Differ. 4: 41-47.

Lowe, S.W. and H.E. Ruley. 1993. Stabilization of the p53 tumor supressor is induced by adenovirus E1A and accompanies apoptosis. Genes \& Dev. 7: 535-545.

Lowe, S.W., H.E. Ruley, T. Jacks, and D.E. Housman. 1993a. p53-dependent apoptosis modulates the cytotoxicity of anticancer agents. Cell 74: 957-967.

Lowe, S.W., E.M. Schmitt, S.W. Smith, B.A. Osborne, and T. Jacks. 1993b. p53 is required for radiation-induced apoptosis in mouse thymocytes. Nature 362: 847-849.

Lüscher, B. and R.N. Eisenman. 1990. New light on Myc and Myb. Part 1. Myc. Genes \& Dev. 4: 2025-2035.

Mack, D.H., J. Vartikar, J.M. Pipas, and L.A. Laimins. 1993. Specific repression of TATA-mediated but not initiator-mediated transcription by wild-type p53. Nature 363: 281-283.

Marcu, K.B., S.A. Bossone, and A.J. Patel. 1992. myc function and regulation. Annu. Rev. Biochem. 61: 809-860.

Martinez, J., I. Georgoff, J. Martinez, and A.J. Levine. 1991. Cellular localization and cell cycle regulation by a temperaturesensitive p53 protein. Genes \& Dev. 5: 151-159.

McDonnell, T.J. and S.J. Korsmeyer. 1991. Progression from lymphoid hyperplasia to high-grade malignant lymphoma in mice transgenic for the $t(14 ; 18)$. Nature 349: 254-256.

Mercer, W.E., M.T. Shields, M. Amin, G.J. Sauve, E. Appella, J.W. Roman, and S.J. Ullrich. 1990. Negative growth regulation in a glioblastoma tumor cell line that conditionally expresses human wild-type p53. Proc. Natl. Acad. Sci. 87: 6166-6170.

Michalovitz, D., O. Halevy, and M. Oren. 1990. Conditional inhibition of transformation and of cell proliferation by a temperature-sensitive mutant of p53. Cell 62: 671-680.

Möröy, T., S. Verbeek, A. Ma, P. Achacoso, A. Berns, and F. Alt. 1991. $\mathrm{E} \mu \mathrm{N}$ - and $\mathrm{E} \mu \mathrm{L}-m y c$ cooperate with $\mathrm{E} \mu$ pim-1 to generate lymphoid tumors at high frequency in double-transgenic mice. Oncogene 6: 1941-1948.
Münger, K., J.A. Pietenpol, M.R. Pittelkow, J.T. Holt, and H.L. Moses. 1992. Transforming growth factor $\beta 1$ regulation of c-myc expression, pRB phosphorylation, and cell cycle progression in keratinocytes. Cell Growth Differ. 3: 291-298.

Nau, M.M., B.J. Brooks, J. Battey, E. Sausville, A.F. Gazdar, I.R. Kirsch, O.W. McBride, V. Bertness, G.F. Hollis, and J.D. Minna. 1985. L-myc, a new myc-related gene amplified and expressed in human small cell lung cancer. Nature 318: 6973.

Philipp, A., A. Schneider, I. Väsrik, K. Finke, Y. Xiong, D. Beach, K. Alitalo, and M. Eilers. 1994. Repression of cyclin D1: A novel function of MYC. Mol. Cell. Biol. 14: 4032-4043.

Pietenpol, J.A., T. Tokino, S. Thiagalingam, W.S. El-Deiry, K.W. Kinzler, and B. Vogelstein. 1994. Sequence-specific transcriptional activation is essential for growth suppression by p53. Proc. Natl. Acad. Sci. 91: 1998-2002.

Pines, J. and T. Hunter. 1991. Cyclin-dependent kinases: A new cell cycle motif? Trends Biol. Sci. 1: 117-121.

Ragimov, N., A. Krauskopf, N. Navot, V. Rotter, M. Oren, and Y. Aloni. 1993. Wild-type but not mutant p53 can repress transcription initiation in vitro by interfering with the binding of basal transcription factors to the TATA motif. Oncogene 8: 1183-1193.

Ramqvist, T., K.P. Magnusson, Y. Wang, L. Szekely, G. Klein, and K.G. Wiman. 1993. Wild-type p53 induces apoptosis in a Burkitt lymphoma (BL) line that carries mutant p53. Oncogene 8: 1495-1500.

Rastinejad, F., M.J. Conboy, T.A. Rando, and H.M. Blau. 1993. Tumor suppression by RNA from the $3^{\prime}$ untranslated region of alpha-tropomyosin. Cell 75: 1107-1117.

Reddy, C.D., P. Dasgupta, P. Saikumar, H. Dudek, F.J. Rauscher III, and E.P. Reddy. 1992. Mutational analysis of Max: Role of basic, helix-loop-helix/leucine zipper domains in DNA binding, dimerization and regulation of Myc-mediated transcriptional activation. Oncogene 7: 2085-2092.

Reed, J.C. 1994. Bcl-2 and the regulation of programmed cell death. I. Cell Biol. 124: 1-6.

Reed, S.I. 1992. The role of p34 kinases in the G1 to S-phase transition. Annu. Rev. Cell Biol. 8: 529-561.

Reisman, D., N.B. Elkind, B. Roy, J. Beamon, and V. Rotter. 1993. c-Myc trans-activates the p53 promoter through a required downstream CACGTG motif. Cell Growth Differ. 4: $57-65$.

Roy, A.L., C. Carruthers, T. Gutjahr, and R.G. Roeder. 1993. Direct role for Myc in transcription initiation mediated by interactions with TFII-I. Nature 365: 359-361.

Shaw, P., R. Bovey, S. Tardy, R. Sahli, B. Sordat, and J. Costa. 1992. Induction of apoptosis by wild-type p53 in a human colon tumor-derived cell line. Proc. Natl. Acad. Sci. 89: 4495-4499.

Shi, Y., J.M. Glynn, L.J. Guilbert, T.G. Cotter, R.P. Bissonnette, and D.R. Green. 1992. Role for c-myc in activation-induced apoptotic cell death in T cell hybridomas. Science 257: 212214

Shibuya, H., M. Yoneyama, J. Ninomiya-Tsuji, K. Matsumoto, and T. Taniguchi. 1992. IL-2 and EGF receptors stimulate the hematopoietic cell cycle via different signaling pathways: Demonstration of a novel role for c-myc. Cell 70: 5767.

Sidransky, D., T. Mikkelsen, K. Schwechheimer, M.L. Rosenblum, W. Cavanee, and B. Vogelstein. 1992. Clonal expansion of p53 mutant cells is associated with brain tumour progression. Nature 355: 846-847.

Spencer, C.A. and M. Groudine. 1991. Control of c-myc regulation in normal and neoplastic cells. Adv. Cancer Res. 56: $1-$ 48. 
Stone, J., T. De Lange, G. Ramsay, E. Jakobovits, J.M. Bishop, H. Varmus, and W. Lee. 1987. Definition of regions in human c-myc that are involved in transformation and nuclear localization. Mol. Cell. Biol. 7: 1697-1709.

Takahashi, T., D. D'Amico, I. Chiba, D.L. Buchhagen, and J.D. Minna. 1990. Identification of intronic point mutations as an alternative mechanism for $\mathrm{p} 53$ inactivation in lung cancer. $J$. Clin. Invest. 86: 363-369.

Tan, T.-H., J. Wallis, and A.J. Levine. 1986. Identification of the p53 protein domain involved in formation of the simian virus 40 large $T$ antigen-p53 protein complex. $J$. Virol. 59: 574 583.

Tilly, J.L. and A.J. Hsueh. 1993. Microscale autoradiographic method for the qualitative and quantitative analysis of apoptotic DNA fragmentation. I. Cell. Phys. 154: 519-526.

van Lohuizen, M., S. Verbeek, B. Scheijen, E. Wientjens, H. van der Gulden, and A. Berns. 1991. Identification of cooperating oncogenes in $\mathrm{E} \mu-m y c$ transgenic mice by provirus tagging. Cell 65: 737-752.

Wagner, A.J., C. Meyers, L.A. Laimins, and N. Hay. 1993a. c-Myc induces the expression and activity of ornithine decarboxylase. Cell Growth Differ. 4: 879-883.

Wagner, A.J., M.B. Small, and N. Hay. 1993b. Myc-mediated apoptosis is blocked by ectopic expression of Bcl-2. Mol. Cell. Biol. 13: 2432-2440.

Wang, Y., T. Ramqvist, L. Szekely, H. Axelson, G. Klein, and K.G. Wiman. 1993a. Reconstitution of wild-type p53 expression triggers apoptosis in a p53-negative v-myc retrovirus induced T-cell lymphoma line. Cell Growth Differ. 4: 467473.

Wang, Y., L. Szekely, I. Okan, G. Klein, and K.G. Wiman. 1993b. Wild-type p53-triggered apoptosis is inhibited by $b c l-2$ in a v-myc-induced T-cell lymphoma line. Oncogene 8: 34273431 .

Wiman, K.G., K.P. Magnusson, T. Ramqvist, and G. Klein. 1991. Mutant p53 detected in a majority of Burkitt lymphoma cell lines by monoclonal antibody PAb240. Oncogene 6: 16331639.

Wolf, D. and V. Rotter. 1985. Major deletions in the gene encoding the $\mathrm{p} 53$ tumor antigen cause lack of $\mathrm{p} 53$ expression in HL-60 cells. Proc. Natl. Acad. Sci. 82: 790-794.

Woodworth, C.D., H. Wang, S. Simpson, L.M. Alvarez-Salas, and V. Notario. 1993. Overexpression of wild-type p53 alters growth and differentiation of normal human keratinocytes but not human papillomavirus-expressing cell lines. Cell Growth Differ. 4: 367-376.

$\mathrm{Wu}, \mathrm{X}$. and A.J. Levine. 1994. p53 and E2F-1 cooperate to mediate apoptosis. Proc. Natl. Acad. Sci. 91: 3602-3606.

Wu, X., J.H. Bayle, D. Olson, and A.J. Levine. 1993. The p53mdm-2 autoregulatory feedback loop. Genes \& Dev. 7: $1126-1132$.

Xiong, Y., G.J. Hannon, H. Zhang, D. Casso, R. Kobayashi, and D. Beach. 1993. p21 is a universal inhibitor of cyclin kinases. Nature 366: 701-704.

Yewdell, J., J.V. Gannon, and D.P. Lane. 1986. Monoclonal antibody analysis of p53 expression in normal and transformed cells. J. Virol. 59: 444-452.

Yonisch-Rouach, E., D. Resnitzky, J. Lotem, L. Sachs, A. Kimchi, and M. Oren. 1991. Wild-type p53 induces apoptosis of myeloid leukaemic cells that is inhibited by interleukin- 6 . Nature 352: 345-347.

Yonish-Rouach, E., D. Grunwald, S. Wilder, A. Kimchi, E. May, J.-J. Lawrence, P. May, and M. Oren. 1993. p53-mediated cell death: relationship to cell cycle control. Mol. Cell. Biol. 13: $1415-1423$.

Zambetti, G.P. and A.J. Levine. 1993. A comparison of the bio- logical activities of wild-type and mutant p53. FASEB I. 7: 855-865. 


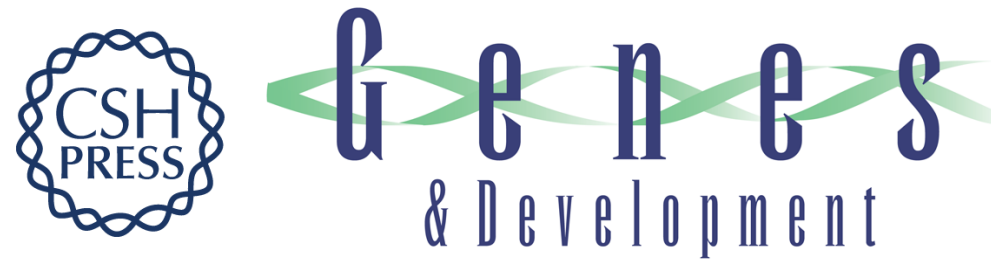

\section{Myc-mediated apoptosis requires wild-type p53 in a manner independent of cell cycle arrest and the ability of p53 to induce p21waf1/cip1.}

A J Wagner, J M Kokontis and N Hay

Genes Dev. 1994, 8:

Access the most recent version at doi:10.1101/gad.8.23.2817

References This article cites 102 articles, 42 of which can be accessed free at: http://genesdev.cshlp.org/content/8/23/2817.full.html\#ref-list-1

License

Email Alerting Service

Receive free email alerts when new articles cite this article - sign up in the box at the top right corner of the article or click here.

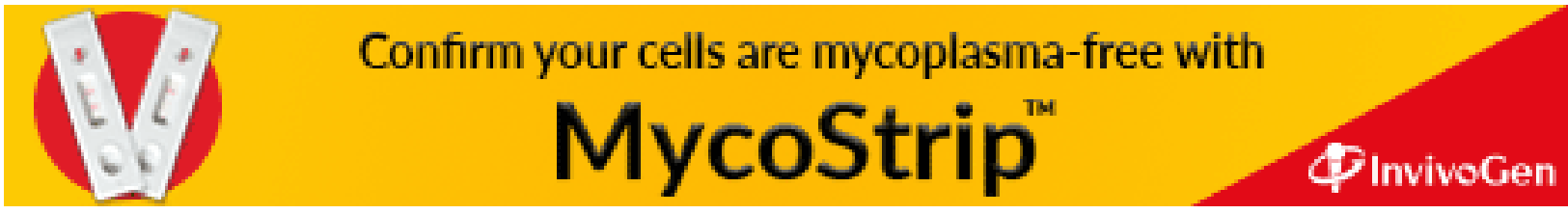

